University of Rhode Island

DigitalCommons@URI

Open Access Dissertations

1979

\title{
CELL PROLIFERATION AND COLLAGEN SYNTHESIS IN EXPLANT CULTURES OF ARTERIOSCLEROTIC RABBIT AORTA
}

Douglas Otto Fisher

University of Rhode Island

Follow this and additional works at: https://digitalcommons.uri.edu/oa_diss

\section{Recommended Citation}

Fisher, Douglas Otto, "CELL PROLIFERATION AND COLLAGEN SYNTHESIS IN EXPLANT CULTURES OF ARTERIOSCLEROTIC RABBIT AORTA" (1979). Open Access Dissertations. Paper 148.

https://digitalcommons.uri.edu/oa_diss/148

This Dissertation is brought to you for free and open access by DigitalCommons@URI. It has been accepted for inclusion in Open Access Dissertations by an authorized administrator of DigitalCommons@URI. For more information, please contact digitalcommons-group@uri.edu. 
CELL PROLIFERATION ANT COLLEGEN SYNTHESIS II

EXPLANT CULTURES OF ARTERIOSCEEROTIC RABBIT AORTA

$3 Y$

DOUGLAS OTTO FISHEP

A THESIS SUBMITTED IN PARTIAI FULEILLMENT OF THE REQUIREMENTS FOR THE DEGREE OF

DOCTOR OE PHILOSOEHY

Iij

PHARMACEUTECAL SCIENCES

(PHARMACOLOGI AND TOXICOLOGY)

$$
\begin{gathered}
\text { CNIVERSITY OE RHOSE ISEAND } \\
\text { i979 }
\end{gathered}
$$




\section{DOCTOR OF PHILOSOPHY DISSERTATION \\ DF \\ DOUGLAS OTTO FISHER}

Approved:

Dissertation Comnittee

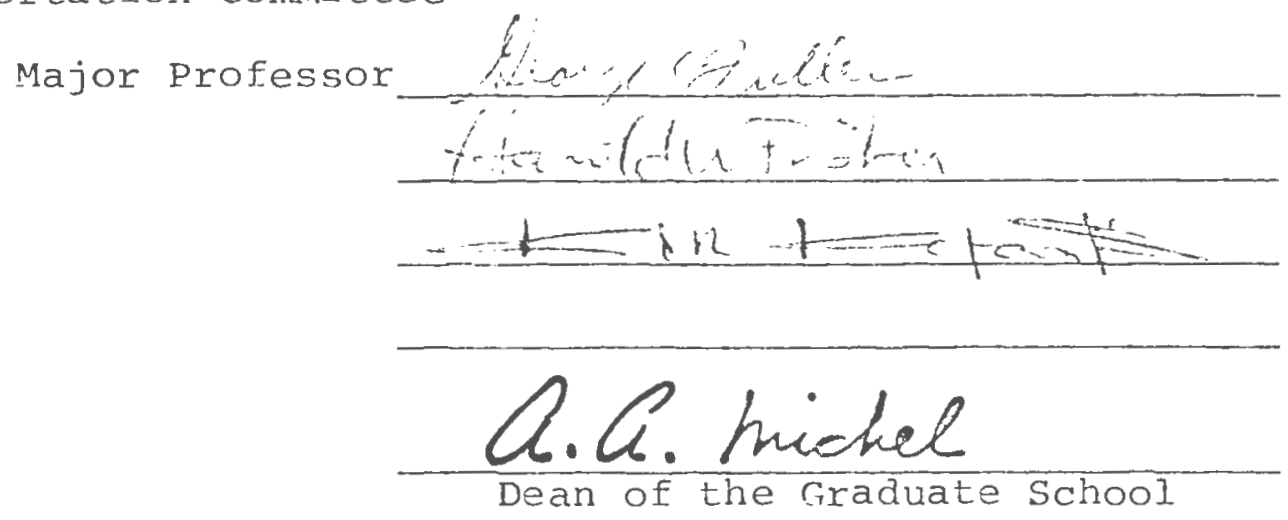

UNIVERSITY OF RHODE ISLAND

1979 


\section{ABSTRACT}

Fisher, Douglas Otto. Ph.D., University of Rhode Island. 1979. Cell proliferation and Collagen. Synthesis in Expiant Cultures of Arteriosclerotic Rabbit Aorta. Major Professor: Dr. George C. Fuller.

The rate of cell proliferation and the ratio of type I/ II collagen synthesized by aorta organ culture and culturea smooth muscle celis (SMC) was deternined in cells derived from rabbits with injury induced (daily epinephrine and thyroxine administration) arteriosclercsis and increased vascular coliagen sÿnthesis. Tissue was taken from medial smooth muscle of normal and diseased rabbits and incubated in organ or cell culture systems with $2,3-{ }^{3}$-proline, ascorbate and beta-aminopropionitrile. Collagen types were separated by SDS-polyacrylamide electrophoresis and CMC-chromatography and quantitated radiometrically. Microscopic observation

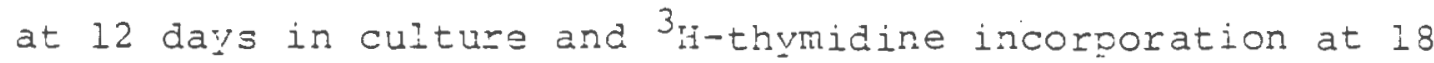
days in culture indicated a greater rate of proliferation of SilC from explants of arterioschlerotic tissue compared to control. In organ culture the ratio of collagen type III: type I was 1 : 1 in the control group and $1: 1.7$ for the arteriosclerotic group. Collagen type III : type I for daughter cells at the end of the 4 th passage was $1: 1.4$ and 1 : 2.0 for control and arteriosclerotic, respectively. By the ioti passage in culture suc in both grouos rere synthesizing almost exclusively tyoe I collagen. This study 
indicates that cells from arterioscierotic smooth muscle ere Iundamentally unique since the ratio of collagen type is controlled by gene expression. This property affecting collagen deposition may play a role in the pathogenesis of vascular disease. 


\section{ACKITWLEDGEMENTS}

The author wishes to express his appreciation to

Dr. George C. Fuller for guidance and encouragement throughout this investigation. Thanks are also conveyed to Ir. David Dezanti for his contributions in support of my gracuate training.

Gratitude is extended to Mrs. Eynne Matoney and Mrs. Nadyis wood for their generous technical assistance at various stages of this investigation. Also acknowledged is Mr. Ronald coldberg for his expertise in gel electrochoresis.

The author extends sincere appreciation to his wife, Kathy, for her continued ercouragement and understanding during his tenure in graduate school.

Financial support for this investigation was provided by AHA $\$ 75-570$ and NIH \#HI16904 grants which were awarded to George C. Fuller. 
TABLE OF CONTENTS

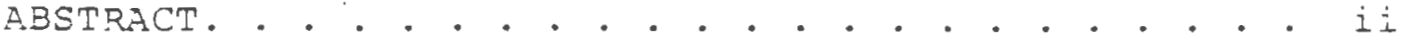

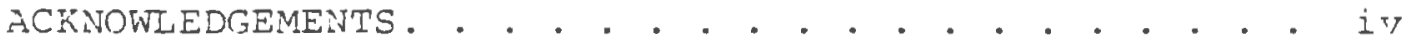
TABLE OF CONTENTS . . . . . . . . . . . . . . . . . V

LIST OF TABLES. . . . . . . . . . . . . . . . . . vii IIST OF FIGURES . . . . . . . . . . . . . . . . . v viii INTROLUCTION. • • . . . . . . . . . . . . . . . . . I LITERATIRE SURVEY . . . . . . . . . . . . . . . . • . 4

The Vascular Connective Tissue Matrix . . . . . . . 4 Response of the Vasculature to Injury . . . . . . 12


RESULTS. . . . . . . . . . . . . . . . . . . . 33

Vascular Smooth : Nuscle Call proliferation. . . . . . 34

Collagen Synthesis inPrimary organ Culture . . . . . . . 36

Collagen Synthesis by Vascular Smooth Muscle Cells

in Culture. . . . . . . . . . . . . . . . . 43

Collagen Heterogeneity by CMC-Chromatography . . . . . . 48 DISCUSSION • • • • • • • • • • • • • • • • • • • • • • • CONCLUSIONS. . . . . . . . . . . . . . . . . . 64

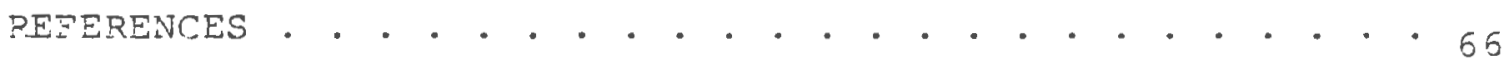

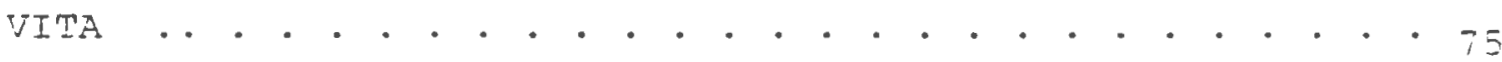


1. Estimation of New Cell Growth from Medial Explants. . . . . . . . . . . . . . .

2. $\quad 3$ H-thymidine Incorporation by Primary Cultures of Medial Smooth Muscle Cells from Control and Arteriosclerotic Rabbits. . . . . . . . .

3. Rate of Synthesis in Organ Culture of ${ }^{3} \mathrm{H}-$ proline Labelled Collagen by Aorta Medial Smooth Muscle from Control and ARteriosclerotic Rabbits. . . . . . . . . . . . . .

4. Rate of Synthesis of ${ }^{3}$ H-proline iabelied Collagen by Cultured Smooth Muscle Cells Derived from Aorta Media of Control and Arteriosclerotic Rabbits. . . . . . . . .

5. Comparison of Electrophoretic and Chromatographic Results for the Synthesis of Type I and Type III Collagens. . . . . . . . . . 


\section{LIST OF FIGURES}

Figure

1. Peripheral Outgrowth of Smooth Muscle Celis from Rabbit Aorta Medial Explants in Culture. . 35

2. Migration of Type I and Type III Collagen Standards on Polyacrylamide Gels Before and After Reduction with 2-Mercaptoethanol. . . . . . . 39

3. Effect of 2-Mercaptoethanol and Bacterial Collagenase Treatment on the Electrophoretic Mirration of $3_{\mathrm{H}-p r o l i n e}$ Labelled Collagen synthesized in Culture by Rabbit vascular Smooth Muscle Cells. • 40

4. Effect of Age in Culture on the Synthesis of Type I and Type III Collagens by Aorta Medial Smooth Muscle Celis from Control and Arteriosclerotic Rabbits . . . . . . . . . . . . 47

5. CMC-Chromatography of Labelled Collagen Synthesized in Organ Culture by Aorta Medial Smooth Muscle from Control and Arteriosclerotic Rabbits. 50

6. CMC-Chromatography of Labelled Collagen Synthesized by Cultured Smooth Muscle Cells Derived from Aorta Media of Control and Arteriosclerotic Rabbits................... . . 51 


\section{INTRODUCTION}

Arteriosclerosis is a complex disease involving many intrinsic and extrinsic factors which influence the susceptibility of the vasculature to insult and the subsequent clinical sequelae. In arteriosclerosis a variable combination of metabolic charges seen in the intima and media of arteries is characterized by "... the focal accumulation of modified smooth muscle cells, lipids, complex carbohydrates, blood and blood products, fibrous tissue and calcium deposits" (Worla Health Organization, 1958). These changes predominate in the major arteries and resistance vessels and by compromising blood flow, account for the clinical appearance of heart attacks, strokes, senility and nemory loss, angina and impaired peripheral circulation.

The major current theories on the genesis of arteriosclerosis share the belief that the lesions begin as localized foci of hyperactive smooth muscle cells in the intima and medial regions of the blood vessels. Authors from this laboratory have reported evidence, using various technicues, which establish the existence of increased collagen synthesis in experimentally induced piacues in aninals. The deposition of collagen in the arterial intima is largely responsible for the occlusive and irreversible nature of arteriosclezosis (Benditt, 1977). It is believed that the 
defect in collagen metabolism which precedes the formation of fibrous vascular plaques is due to a change in the growth characteristic and function of smooth muscle cells, the predominant cell type in the arteriosclerotic intima.

Four genetically distinct types of collagen are currently recognized and, although their distribution is tissue specific, various disease processes and aging can be correlated to altered distribution of collagen type. For examele, type I collagen is the predominant extractable collagen species in human fibrous atheromatous plaques whereas type III appears to be the major aortic medial collagen (McCullagh and Balian, 1975). Iittle is known about the control of collagen heterogeneity but it could be proposed that a change in collagen gene expression, as a result of smooth muscle cell transformation, may be associated with the development of arteriosclerosis.

This investigation was conducted to examine the inypothesis that the arteriosclerotic lesion in rabbits is associated with a distinct population of smooth muscle cells with altered growth characteristics and function, suggestive of cellular transformation. To examine this hypothesis the growth characteristic of celis from primary cultures of control and arteriosclerotic rabbit aorta were examined. Also, studies were conducted to aetermine if aughter celis derived From medial tissue explants of arteriosclerotic plaques continue to synthesize a similarly abnormal ratio of type I 
to type III collagen compared to smooth muscle cells derived from explants of normal aorta. It is believed that these studies are valuable to gaining an understanding of the rormal regulation of collagen synthesis and perhaps in screening for useful drugs in the treatment of abnormalities in collagen metabolism which occur in various disease states. 


\section{LITERATURE STTRVEY}

\section{The Vascular Connective Tissue Matrix}

The intercellular matrix of the arterial wall contains four major types of macromolecules icollagen, glycosaminoglycans, elastin and glycoproteins). Most chemical studies have beer carried out using the aortas of different animal species; only limited information is available on other arteries or veins. Several reviews discuss the chemical and biological characteristics of these macromolecules (Balazs, 1970; Robert, 1970; Slavkin, 1972). Much of the early knowledge on the chemistry and biosynthesis of elastin was gained from experimental work by Partridge (1970, 1972). Several laboratories have studied the composition and biosynthesis of glycosaminoglycans and glycoproteins in normal and pathological arterial walls (Engel, 1971; Kumar et al., 1967; Moczar and Robert, 1970; Srinivasan et al., 1971). Considerable interest in arterial collagen has been generated by research which demonstrated its dynamic role in experimental atherosclerosis (Levene, 1962; Smith, 1965; Fuller et al., 1970, 1972, 1973, 1976; Crossley et al., 1972; Ooshima et a1., 1974). As a result various laboratories began isolating and characterizing aortic coliagen genetic types (Chung et $31 ., 1974$; Lpstein et al., 1975; Trelstac, 1974; MCCullagh and galian, 1975). 
Collagen synthesis occurs in a series of sequential steps consisting of assembly of a proline-rich and lysinerich polypeptide precursor of collagen (procollagen aipha chains) enzymatic hydroxylation of some of the prolyl and lysyl residues and glycosylation of some of the hyaroxylysyl residues. The cellular processing of the procollagen alpha chains also includes formation of the triple helix with stability provided by disulfide bonds in the nonhelical regions of the molecule (Bornstein and Ehrlich, 1973 ). Following secretion, these nonhelical regions are removed by the extraceliular enzyme procollagen peptidase (Lapiere et al., 1971; Goldberg, et al., 1975). The crosslinking of collagen, which imparts stability to helical and fibrillar collagen, occurs through further extracellular processing by the enzyme lysyl oxidase which oxidatively deaminates specific lysine residues leaving aldehyde moieties which form cross links through condensation reactions (Siegel et al., $1970)$.

Data reported by several laboratories, during recent years, reflects some inconsistency in expressing collagen content. Factors which introduce variability include: species, pathological condition, age, method of isolation and anatomical region. The experimental studies also indicated that a determination of totai content as well as concentrations is necessary for a correct evaiuation of the metabolic alterations of the macromolecules in studies on 
vascular injury (Helin et al., 1971). In a recent study of canine atherosclerosis the percentage of protein synthesis represented by collagen rose from a mean of less than 5 in normal aortic branch arteries to $14 \frac{3}{3}$ in severely atherosclerotic branch arteries, showing that the increases in collagen synthesis were not associated simply with an overall increase in protein synthesis (McCullagh and Ehrhart 1974). Langner and Euller (1973), reported increased total collagen and $0.45 \mathrm{M}$ NaCl soluble collagen in thoracic aorta of rabbits with epinephrine-thyroxine induced arteriosclerosis. The collagen content of an apparently normal human coronary artery approximates $25 \mathrm{mg} / 100 \mathrm{mg}$ of dry, defatted tissue (Tamai et al., 1978). In arteriosclerosis the wet weight of a vessel increases and therefore content of vascular components can be misleading when expressed on the basis of organ wet weight (Tammi et a1., 1978). In another study collagen was reported to comprise $30 \%$ of the dry weight of human fibrous atherosclerotic plaques (Ievene and Poole, 1962).

Aortic prolyl hydroxylase has been used as a marker of collagen synthesis (Fuller and Langner, 1970; Fuller et al., 1972) and has been shown to increase up to six-fold in an experimental modei of arteriosclarosis in rabbits and in aorta of miniature pigs fed a lipid-rich diet. Kinetic properties of this enzyme and the existence of immunologicalIy cross-reacting forns of the prolyl hydroxylase have been 
investigated for their potential role in regulating the rate of collagen synthesis (Fuller et al., 1976; Doshima et al., 1974). The $V_{\max }$ of prolyl hydroxilase in an organ affected by arteriosclerosis increased four-fola, compared to controls, while the $\mathrm{Km}$ remained uncharged (Fuller et al., 1976). Various parameters of collagen synthesis including immunologically related protein are elevated in rats with hypertension induced by deoxycorticosterone acetate-salt looshima et al.. $1974)$.

During the mid-seventies advancements in connective tissue methodology led to the separation and identification of three distinct species of collagen (gene products) from human aorta (Trelstad, 1974). These included principally type I and III collagens, along with small amounts of type IV which is associated with basement membranes. Type I collagen is composed of two, $\alpha 1$ chains and one, $\alpha 2$ chain and designated by the nomenclature as $[\alpha 1(I)]_{2} \alpha 2$. Type III collagen is composed of three identical $\alpha$ l(III) chains, designated $[\alpha]$ (III) $]_{3}$ and has the distinction of containing disulfide bonds between the $\alpha$-chains. It should also be mentioned that type II collagen is found in cartilage and invertebral disc and is represented according to the nomenclature as $[\alpha{ }(I I)]_{3}$. Therefore, a total of four genetically distinct types of collagen have been isolated and characterized by modifications of standard electrophoretic or chromatographic methods (Miller et al., 1971). There are at least 
five structural genes involved in the synthesis of the different types and the transcription of these various genes seems to be tissue specific.

McCullagh and Belian (1975) have suggested that in addition to the increased accumulation of collagen reported in arteriosclerosis an alteration in the ratio of collagen types may have important imolications. Their investigations using pepsin extracted collagen from blood vessels indicated the composition was approximately 70\% type III and $30 \%$ type I. In contrast, collagen extracted from atherosclerotic blood vessels contaired 35\% type III and 65\% type I. Another component of the vascular conrective tissue matrix is the glycosaminoglycans, which include hyaluronic acid, heparin sulfate, chondroitin 4-sulfate, chondroitin 6-sulfate and dermatan sulfate. These macromolecules, which occur linked to proteins, are composed of repeating units of substituted hexoses, such as $N$-acetyl-D-glucosamine. Some of them carry the distinction of being sulfated. The glycosaminoglycans (GAGs) are jellylike, sticky or slippery substances that provide intercellular lubrication and act as a flexible cement. New knowledge is available concerning the structure and biosynthesis of these substances in the aorta of several species. The methods used in current investigations involve separation and fractionation by digestion with hyaluroniase and CPC-cellulose nicrochromatography (Thunnel, 1967). The GAG fractions can be 
quantitated by measuring hexosamine content (Boas, 1933). Great variations between species nave been reported for both total GAGs per $\mathrm{mg}$. dry aorta or $\mathrm{mg}$. DNA and in the relative distribution of different GAGs (Engel, 1971). Reports on the changes of these substances in human arteriosclerosis do not completely agree (Helin et al., 1970) (Tammi et al., 1978). However, most agree that chondroitin 4-6 sulfate is the principle GAG in the large human arteries.

The interactions of collagen with glycosaminoglycans has been a subject of investigation for a number of years (Mathews, 1965). By electron microscopy a regularly distributed parallel or transverse alignment of the GAG molecule, along the collagen fibril, has been visualized (SerafiniFrancassini et al., 1970). Ruthenium red-positive filaments interconnecting collagen fibers have been demonstrated in rat aorta (Kajikawa, 1970). Lysine and hydroxylysine residues as well as the glycosidically bound carbohydrates in collagen participate in the interactions between collagen and GAGs. Ionic interactions as well as nydrogen-bond formation could be significant contributors to the integrity of connective tissues. It is quite likely that highly glycosylated collagen, like type II, is most dependent on such types of interactions, particularly since it is found in areas rich in glycosaminoglycans (Nimni, 1974 ). Similar to the glycosaminoglycans which occur linked to proteins, the glycoproteins are compiex polysaccharides 
found linked to lipids as well as protein. A large number of proteins can be classed as glycoproteins because of the presence of an oligosaccharide moiety. The term glycoprotein is frequently restricted to those proteins that cortain small amounts of carbohydrate, iess than 4 zz hexosamine. Seven sugars account for almost all the carbohydrate residues in mammalian glycoproteins. With the exception of L-fucose, the other sugars are of the D configuration: N-acetylglucosamine, N-acetylgalactosamine, galactose, mannose, sialic acid and glucose. The last (glucose) occurs only in proteins of the collagen type where hydroxylysine is linked to galactose by a glycosidic bond.

Glycoproteins have been extracted by several authors from aortic tissue and some of the glycoproteins were purified and characterized (Moczar and Robert, 1970; Moczar et al., 1970). An elevated level of glycoproteins was reported in arteriosclerotic intima by dullinger and Manley (1969), confirming preceding studies by Nakamura (1968) and Schoerbeck et al. (1962). Srinivasan (1971) reported the presence of tissue specific glycoproteins in several connective tissues, including aorta. Similar structural glycoproteins were isolzted from elephant aorta by McCullagh et al. (1973). It was shown that elephant glycoproteins cross-react with antibody raised against human aorta structural glycoproteins. It was suggested that there is an organ-specific immunochemical pattern for these substances. 
This evidence was consistent with an earlier proposition that structural glycoproteins could represent the primitive (phylogeneticaliy) intercellular macromolecular meshwork onto which the more elaborate collagen and elastin fibers are deposited.

Elastin is the most specific and conspicuous macromolecular component of the intercellular matrix of young large arteries, such as aorta. The amino acid composition of elastin, established by Partridge (1963) strongly suggests that hydrophobic interactions provide the stabilizing forces responsible for its tertiary and quarternary structure. Robert and Poullain (1964), proposed the hydrophobic hypothesis of elastin elasticity which has been confirmed by more recent findings (Hoffman, 1971). It is not within the scope of this literature survey to thoroughly address the most current investigations on the physiochemical properties and biosynthesis of elastin (see Ross and Bornstein, 1969; Abraham et al., 1975). However, it would be appropriate to stress that the fragmentation-degradation of elastic fibers and laminae is one of the most conspicuous findings of the atherosclerotic changes in aortas. This is observed in the human atherosclerotic plaque and it seems to be independent of the method used to induce experimental arteriosclerosis. Neutrophil granulocytes (Janoff, 1970) and blood platelets were shown to contain proteases with elastolytic activity (Legrand et al., 1973) and it is quite srobable 
that similar enzynes may be isolated from aorta, where the degradation of elastin during atheroscierosis has been demon-strated.

\section{Response of the Vasculature to Injury}

The repair processes have been proposed to be characteristic features in various vascular diseases, among these arteriosclerosis and vasculitis (helin et al., i972). Mechanical strain and the subsequent inflammation has been shown to be an important initiating factor in the development of aortic arteriosclerosis in rabbits subjected to systemic hypoxia and intravenous injections of catecholamine (Helin ana Lorenzen, 1969; Crossley et al., 1972). The investigations by these and other authors have established significant relationships between vascular repair following injury and atherogenesis (Helin et al., 1971; Hartman, 1977; Kobaysi, 1969). The nature of the repair and the ultimate outcome of the entire process depends, among other Eactors, upon the characteristics of the injurious agent, duration of exposure to it, the type of initial local manifestations and mural reactions and the status of the host. Owing to the peculiarities of structure ard function, the arterial wall has Iimited versatility in defense mechanisms and the defense forces are hampered not only by the lack of mural capillaries but also by the fact that the artery is never at rest and thus an importanc healing-promoting factor is absent. 
A number of the established processes in inflammation and repair are operative Eollowing vascular injury and have been reviewed in detail (Robbins, 1974). Two tissue zeactions are characteristically observed in atherosclerosis and appear to be unique for this disease process. One is the regressive change of intimal smooth muscle cells with lipid accumulation representing fatty metamorphosis. Smooth muscle cells elsewhere in the body are not known to underco fatty metamorphosis. The other unusual feature in atherosclerosis is the formation of the repair tissue that is avascular but contains modizied smooth muscle cells which are responsible entirely for the organization and connective tissue elaboration. These two events give rise to progressive diffuse intimal thickening and fibrous plaque formation which are the characteristic lesions of arteriosclerosis.

\section{The Role of the}

Smooth Muscle Cell in Arteriosclerosis

Evidence that intimal smooth muscle, or a closely related cellular derivative, is involved in the formation of connective tissue during atherosclerotic intimal thickening of elastic anc muscular artiers has been reported in both human and experimentally induced atherosolerosis (Haust et a1., 1960; Geer and Haust, 1972; Ross and Glomset, 1972). It is not ciear whether the modified smooth muscle found 
in the intima orginates in the intima or migrates from the media. At birth most of the smooth nuscle celis are located in the medial layer of arteries and the intima is comparatively thinner and contains only a few smooth muscle cells. The internal elastic lamina represents a morphological border between the intima and the media. Fragmentation of the elastic lamina has been shown to be associated with various forms of mechanical injury to the vasculature and would thus permit the migration of medial smooth muscle into the intima (Ross and Glomset, 1973). It has also been suggested that the intact arterial endothelium normally acts as a barrier to some substances present in the plasma which upon exposure to vascular smooth muscle promote cell proliferation (Ross and Glomset, 1973). Smooth muscle cells have been reported to accumulate in the intima at those sites in the arterial vascular bed where endothelial permeability appears to be increased (Helin et al., 1972).

Benditt (1977) proposed that cells comprising atherosclerotic plaques have undergone mutational changes which are analogous to the transformation process occurring in benign tumor cells. This premise is based on the observation that cells within the plaques are monoclonal in oriain with respect to glucose-6-phosphate dehydrogenase isoenzyme patterns (Benditt and Benditt, 1973). These cells aiso have morphological and functional features which are different from normal smooth muscle cells in the arterial wall (Somlyo and Somlyo, 1968). 
The Smooth Muscle cell in Culture

Tissue culture, since it was introduced at the turn of this century, has undergone several stages in its evolution. In its present phase emphasis is placed on the analysis of cellular interaction, cell differentiation, and cell function. Initial experiments have been conducted, establishing the growth characteristics of normal rabbit smooth muscle cells in tissue culture (Ross, 1973; Doaud et al., 1964).

A pure population of smootin muscle cells can be isolatea from the tunica media of the aorta or large blood vessels of most mammals. Therefore, if the adventitia and intima are stripped off such vessels, the remaining tunica media is a source of pure smooth muscle cells for culture. In culture, smooth muscle cells first acquire a fibroblastIike appearance. During this stage many cells degenerate but others proliferate. After a Iew weeks in culture the daughter cells accuire the appearance of smooth muscle celis (Ross, 1971). Their identity can be easily established by electron microscopy because by then, they again contain considerable amounts of myofilaments in their cytoplasm. The actomyosin in these cells can be demonstrated by immunohistochemical methods (Knieriem et al., 1968). The similarity of these cells to cells in atherosclerotic lesions make them a potentially important tool for atherogenesis research. 
Kokubu and Pollak (1961) observed that diseased arterial tissue from cholesteroi fed rabbits showed better celluiar outgrowtin, after being placed in culture, than sormal tissue. In contrast to this Wexler and Thomas (1967) reported that explants from arteriosclerotic breeder rats had a lower growth curve than those from virgin rats. Fritz and co-workers (1976) have been studying vascular smooth muscle for a number of years and have recently published information on protein synthesis and its relation to DNA synthesis ir aortic mediai explants. Their system consisted of free floating explants of swine aorta media. Over an 18 day period grotein synthesis ( ${ }^{14} C^{-l e l u c i n e}$ incorporation) paralleled DNA synthesis ( ${ }^{3} \mathrm{H}$-thymidine incorporation). This is in agreement with the generalization that protein turnover in slowly metabolizing cells without cell division is minimal. However it was pointed out by Osaki and Holtzer (1966) that for myogenesis to occur, cells must withdraw from mitotic cycle for 5 to 3 hours of $G_{1}$ before myosynthesis. Further studies of this nature are definitely warranted to better establish rolationships between cell proliferation and the synthesis of specialized proteins such as collagen and elastin, particularly with regard to specific stimulatory factors which may exist in serum and platelets.

Conspicuous accumulation of lipids by smooth muscle ceils existing in regions os arteriosclerotic lestons has been mentioned earlier in this review. Cultured arterial 
smooth muscle cells provide a useful system for studying the differential effects of hyperlipemic serum and isolated lipoproteins (St. Clair and Leight, 1978; Bates and vissler, 1976). These studies suggested that differences in the serum composition of lipoproteins resulting from genetic, dietary or other environmental influences may play an important role in determining the efficiency of delivery of cholesterol to vascular smooth muscle cells and perhaps ultimately its atherogenic potential.

Various studies, many of which have been cited in a resent review by Ross and Vogel (1978), support a hyoothesis that, in the absence of platelet function, the intimal smooth muscle proliferative lesions of atherosclerosis can be prevented. Therefore it is important to this discussion to acknowledge that considerable current interest is being devoted to understanding not only the mode of action of platelet factors in cell culture, but its role in the stimulation of a number of important in vivo proliferative cellular responses.

\section{Cell Iransformation and the Collagen Phenotype}

ledial smooth muscle cells are specialized meserchymai cells of the vasculature. The structural integrity of the vessel wall depends upon the normal functioning of these cells. It seems logical that a change in the differentiated state of vascuiar smooth muscle phenotype could lead 
to the production of an abnormal matrix and to a loss of structural stability of such a tissue. Benditt (1973) has proposed that cells comprising atherosclerotic plaques have undergone mutational changes which are analogous to the transformation process occurring in benign tumor cells. This theory could be tested by determining if there is a change in the heterogeneity of vascular collagen synthesized by smooth muscle cells from arteriosclerotic vessels, since collagen types are genetically prescribed.

A substantial amount of the information concerning cell transformation and collagen synthesis has been obtained from studying the transformation of chondroblasts into fibroblasts. Recently it has been shown that when chick chondrocytes are grown in brom-deoxyuridine (BUdR) for a few days, collagen biosynthesis will switch from cartilage specific type II collagen (chain composition $\left.[\alpha I(I I)]_{3}\right]$ to a mixture of type I collagen (chain composition $[\alpha I(I)]_{2}{ }^{2}$ and the trimer (chain composition $[\alpha I(I)]_{3}$ (Mayne et al., 1975). More recent investigations by that group showed that embryonic chick chonarocyte possesses an inherent and latent program of differentiation that involves "collagen switching" and by growing these cells in vitro it is possible to potentiate this program (Mayne et a1., 1976). The altered morphology of chick chondrocytes due to BUdR and due to cellular senescence was very similar.

Another study reported that in suitable medium, chick chondrocytes retain the morphology characteristic of 
cartilage tissue and synthesize a matrix whose main constituent is chondroitin sulfate. When chick embryo serum was added to the culture medium the cells attained a fibroblastlike morphology and stopped synthesizing chondroitin sulfate (Marzullo and Lash, 1970). These authors proposed that under suboptimal conditions, competition between two kinds of synthesis for limiting levels of energy metabolites may faror cell division over the production of tissue specific molecules. These tissue specific molecules could be considered luxury molecules which are expendable and non-essential for survival of a cell (Holtzer and Abbot, 1968). This is consistent with the findings of Mayne et al. (1975) who observed that the change in the phenotype of chick chondrocytes grown in BUdR was characterized by an increase in DNA synthesis, failure to accumulate extracellular matrix and a "transformation" into motile cells that resemble fibroblasts.

It is therefore not surprising that somewhat similar variability in the synthesis of collagen types has been reported for medial smooth muscle cells in culture (Iayman and Titus, 1975; Barnes et al., 1976; Scott et a1., 1977). The differences in the proportion of type I and III collagens by these cells in culture may be a reflection of cell line variability or differences in growth conditions employed. Although it may be argued that such in vitro conditions hardly resemble the in vivo situation (Fowler et al., 1977) it seems apparent that further studies if properly designed, 
would be helpful in learning more about the regulation of collagen heterogeneity and influences by the extraceliular matrix on gene expression. An understanding of those factors controlling collagen synthesis is basic to our understanding of several disease processes including atherosclerosis.

\section{Collagen Heterogeneity: Pathological Implications}

Changes in the relative proportions of collagen types within a tissue may occur in various disease states (Pope et al., 1975; McCullagh and Belian, 1975; Seyer et al., 1976; Penttinen et al., 1975). In one of these studies the importance of type III collagen was indicated by the susceptibility of large arteries to rupture in patients with Ehler's Danlos syndrome (Type IV) who exhibited reduced levels of type III collagen in these tissues (Pope et al., 1975). It has been suggested that the arteriosclerotic plaques represent scar tissue, because a mixture of type I and II collagens with a predominance of type I appears to be typical of wounds.

During fetal development, the proportion of type I and type III collagen nolecules forming the dermis shifts from a large proportion of type III to increasing amounts of type I (Epstein, 1974). Concomitant with this are changes in mechanical properties and coarsening of the bunde fibers (Pierard et al., 1976). Such variations in bunde 
organization observed in vivo occur in the same range of concentration as the most striking changes in bundle architecture produced during in vitro assembly, i.e. from pure type I to $30 \%$ type III and $70 \frac{3}{5}$ type I. Work based on in vitro reconstitution of type I and type III collagen polymers, demonstrated that the chemical structure of collagen molecules determines the physical structure of the bundles, type I forming thick bundles of fibers and type III thin, isolated fibers and mixtures of both type $I$ and type III, bundles with thickness varying with the respective concentrations of the two types of molecules (Lapiere and Pierard, i977).

Whatever the mechanism of the interaction of the collagen types, it appears important during development and in patholcgical conditions. It would explain the resistance to stretching observed for thick bundles of type I collagen in tendon in contrast to the laxity ard the distensibility of the blood vessel wall, which contains a mixture of type I and type III collagens (Lapiere and Pierard, 1977). Also, Hughes et al. (1976) has reported that in vitro platelets are known to adhere better to type III collagen than to type I. However, there are arguments regarding the correlation and interpretation of in vitro experiments involving type-specific-collager:platelet interactions.

It has not been established if type I and type III collagens form two populations of Eibers or one population composed of type I and type III molecules. In all the 
conditions mentioned above the altered collager composition and the increased proportion of type I are accompanied by the presence of coarser bundles and impaired mechanical functions. Although type III $\alpha$-chains have the distinction of containing two, half-cysteine residues, there are no contrasting features regarding the elemental composition of each type which could better explain the individual and composite architectural properties of collagen type I and III. 


\title{
EXPERIMENTAL
}

\begin{abstract}
Animals
Male albino New Zealand rabbits weighing 3 to 4 pounds were obtained from Glocester Rabbitry (Glocester, Rhode Island) at least one week prior to the start of the experiments. The animals were housed in pairs in a room maintained at an ambient temperature of $24^{\circ}-27^{\circ} \mathrm{C}$., with alternating 12 hour light/dark cycles. All animals were offered a commercial laboratory chow and water ad libitum.
\end{abstract}

\section{Materials}

Analytical grade reagents were used throughout the investigation. The following drugs were purchased: L-epinephrine bitartrate and L-thyroxine (Eree base) (Sigma Chemical Company, st. Louis) and 3-aminopropionitrile fumarate (Aldrich Chemical Company, Milwaukee). The radioactive amino acid $2,3-{ }^{3} \mathrm{H}-\mathrm{L}$ proline (spe-j.fic activity aporoximately $20 \mathrm{Ci} / \mathrm{mMo}$.$) and methyl- { }^{3} \mathrm{H}$-thymidine $(52.1 \mathrm{Ci} / \mathrm{mMol})$ were purchased Erom New England Nuclear Corporation (Boston). Chromatographically purified clostridial collagenase was obtained from Açvanced Biofractures, Inc. (Lynbrook, jen York) and pepsin (2500 i/mg) from worthington (Freehold, N.J.). The purity of the coliagenase was confirmed by its 
inability to degrade ${ }^{14}$ C-tryptophan labeled E. coli protein. Type I and Type III collagen standards were prepared by Ronald Goldberg (U.R.I.) by differential salt precipitation of acetic acid solubilized newborn calf skin.

Electrophoretic grade acrylamide and $\mathrm{N}, \mathrm{N}^{\prime}$-methylene-bisacrylamide, $N, N, N^{\prime}, N^{\prime}$-tetramethylethylenediamine and docecyl sodium sulfate were purchased from Eastman Rodak Co. (Rochester, N.Y.). Carboxymethylcellulose CM52 (Whatman, Kent, England) was used for chromatographic analysis.

Biologicals for the cell culture and organ culture systems were obtained from Gibco (Grand Island, V.Y.) and included: Dulbecco's Modified Eagle Medium (with glutamine), fetal calf serum (heat inactivated), amphotericin-B (250 $\mathrm{mcg} / \mathrm{ml})$, Penicillin-Streptomycin $(10,000 \mathrm{U} / \mathrm{ml}-10,000 \mathrm{mcg} / \mathrm{ml})$ and pancreatin (2.5\%).

\section{Epinephrine-Thyroxine Induced Arteriosclerosis}

Gross aortic piagues were induced in male New Zealand rabbits by daily injections of epinephrine and thyroxine for 15 days (Fuller et al., 1976). Epinephrine (0.025 $\mathrm{mg} / \mathrm{kg}$ for the first 5 days; $0.05 \mathrm{mg} / \mathrm{kg}$ thereafter) was injected via the marginal ear view with an infusion pump (Harvard Apparatus Company Inc., Model 940, Dover, Massachusetts). Thyroxine $(0.05 \mathrm{mg} / \mathrm{kg})$ Ireshly grepared was injected intraperitoneally. Animais were killed by cervical dislocation 24 hours after the last injection. The thoracio 
aorta was removed under aseptic conditions and rinsed with cell culture medium. The adventitia and endothelium from plaqued regions and from analogous regions of untreated control rabbits was removed. The remaining intimal-medial tissue was cut into $1 \mathrm{~mm}^{2}$ pieces which served as the source of aorta smooth muscle for organ culture and for growing cultures of smooth muscle cells (Fedoroff, 1973).

\section{Organ culture system}

Approximately $50 \mathrm{mg}$ aliquots of freshly dissected medial smooth muscle from each anima? were placer individualiy in $2 \mathrm{ml}$ of Dulbecco's Modified Eagle Medium (DMEM) containing $100 \mathrm{ug} / \mathrm{ml}$ of 3-aminopropionitrile (EAPN) and $400 \mathrm{ug} / \mathrm{ml}$ of ascorbate. After a 2 hour preincubation at $37^{\circ} \mathrm{C}$ in $5 \% \mathrm{CO}_{2}-95 \frac{z}{3}$ air, $100 \mathrm{uCi}$ of $2,3-3^{3} \mathrm{H}-\mathrm{L}$ proline was added to each sample. Incubation was resumed for another 70 hours, after which the samples were transferred to a freezer for storage. Labelled collagen was extracted by first homogenizing the smooth muscle tissue in its $2 \mathrm{ml}$ incubation media using $\exists$ conical ground-glass homogenizer. A 400 ul portion of this homogenate was taken for DNA determination accorcing to the method of Burton (1956). The remainder of the sample was dialyzed against $0.5 \mathrm{M}$ acetic acid and then treated with pepsin $(100 \mathrm{ug} / \mathrm{ml})$ at $4^{\circ} \mathrm{C}$ 三or 12 hours. After limited proteolysis of noncollagenous protein, tissue debris was remored by centrifugation at 30,000 rpm for 20 minutes. 
The supernate was then dialyzed for 12 hours, against 0.05: phosphate buffer $(\mathrm{pH} 7.2)$ and the volume adjusted to $1.6 \mathrm{mI}$. Aliquots of these samples could be combined with electrophoresis buffer, heat denatured $\left(56^{\circ} \mathrm{C} \times 20\right.$ minutes) and the labelled alpha chains separated on $5 \frac{q}{5}$ polyacrylamide gels according to the method of Nevilie (1971).

\section{Culturing of Smooth Muscle Cells}

A portion of the medial tissue was also used as explant culture to derive colonies of smooth muscle cells for each of the experimental animals. The $60 \mathrm{~mm}$ Falcon petri dishes, each containing approximately 5 to 10 self-adhering explants from a specific animal, were flooded with $10 \mathrm{ml}$ of DMEM. This medium contained $20 \%$ fetal bovine serum, penicillin $(100 \mathrm{U} / \mathrm{mI})$, streptomycin $(100 \mathrm{ug} / \mathrm{ml})$ and amphotericin $\mathrm{B}$ $(2.5 \mathrm{ug} / \mathrm{ml})$. The explant cultures were incubated at $37^{\circ} \mathrm{C}$ in an atmosphere of $5 \frac{8}{3} \mathrm{CO}_{2}-95 \frac{7}{3}$ Air. After the appearance of sufficient marginal outgrowth from the explants (about 18 days) the media was removed and the cultures rinsad with phosphate buffered saline (pH 7.0). The cells were detached by a 15 minute incubation at $37^{\circ} \mathrm{C}$ in $0.25 \%$ Pancreatin (N.F.) solution ( $\mathrm{pH} 7.4$ ) and transferred to new $60 \mathrm{~mm}$ petri dishes with fresh mediun containing serum. This pancreatin solution, used in the manner described by Merchant et al. (1969), was more effective in removing cells Erom the 
culture flasks than $0.25 \%$ trypsin solution. Subculturing was performed at least once a week thereatter, or whenever a dish reached confluency. By seeding successively larger dishes a population of $5 \times 6^{10}$ celis/75 $\mathrm{cm}^{2}$ was reached at about the 4 th passage. At the end of the 4 th passage fresh medium (DMEM) was adaed which contained only loz fetal bovine serum plus $100 \mathrm{ug} / \mathrm{ml}$ BAPN, $400 \mathrm{ug} / \mathrm{ml}$ ascorbate and $2 \mathrm{uCi} / \mathrm{ml} \mathrm{2,3-}$ ${ }^{3} \mathrm{H}-\mathrm{I}$ proline. This system was incubated under the conditions described above, for 12 hours. After incubation the media was removed and stored frozen. The cell layer, for measurement of total DNA, was removed with 0.1 : Pancreatin solution (Gibco) and the cell pellet stored in the freezer.

The medium from each flask was treated with $50 \%$ ammonium sulfate to precipitate protein. The precipitate was redissolved in $1 \mathrm{ml}$ of $0.5 \mathrm{M}$ acetic acid containing $20 \mathrm{mcg}$ of pepsin and dialyzed in the same manner for 12 hours at $4^{\circ} \mathrm{C}$. The pepsin was inactivated by redialyzing against $0.05 \mathrm{M}$ phosphate buffer (pH 7.2). After dialysis each sample was adjusted to $2.0 \mathrm{ml}$ with $0.05 \mathrm{M}$ phosphate buffer (oH 7.2) and stored in the freezer.

Thymidine Incorporation by Explant Cultures of Vascular Smooth Muscle Cells

Labelied thymidine incorporation was measured at day 18 in explant cultures prepared as described above. Each $60 \mathrm{~mm}$. dish contained 5 explants ( $1 \mathrm{~mm}^{2}$ ) and all five explants 
were taken from the same animal. Five replicate dishes were prepared for each animal. At the 17 th day of incubation under the previously described conditions, the mediun was replaced. On the i8th day 0.01 uCi of ${ }^{3}$ H-thymidine was added to each petri dish andincubated for 8 hours. The medium was removed and the cells detached with $1 \mathrm{ml}$ of $0.25 \%$ pancreatin solution. The cell suspensions were precigitated with ice-cold 5 z trichloracetic acid (TCA) and the pellet washed 3 times with $2 \mathrm{ml}$ volumes $5 \% \mathrm{TCA}$. The washed pellets were sonicated in $1 \mathrm{ml}$ of $0.5 \mathrm{~N}$ perchloric acid. The radioactivity was determined in $200 \mathrm{ul}$. aliquots of the perchloric acid in solution Hydromix ${ }^{3}$, by liquid scintillation spectrometry.

\section{Polvacrylamide Gel Electrophoresis}

The 58 polyacrylamide gels and electrophoresis buffers used in this part of the study were prepared by the methods described by Neville (1971). To a 50 ul. aliquot of each sample, described above, 50 ul. of sample preparation buffer was added. This sample preparation buffer consisted of $.02: 1$ phosphate buffer (pH 7.2), 211 urea, 0.28 sodium dodecyl sulfate, $10 \%$ sucrose and contained $1 \mathrm{mg} / \mathrm{ml}$ of a $1: 1$ mixture of purified type I and type III calf skin collagen. aach sample was prepared in duplicate; one of which was made $2 \frac{2}{3}$ with mercaptoechanol to reduce the disulfide linkages in type III collagen. All sampies were then heat 
denatured for 20 minutes in a $56^{\circ} \mathrm{C}$ water bath. Aliquots of the reduced and unreduced (100 ul, each) were loaded onto separate gels and electrophoresed at 2 mamps per gel for approximately 2.5 hours. The gels were then stained in $0.5 \mathrm{M}$ acetic acid containing $0.25 \%$ coomassie blue. The regions corresponding to the collagen alpha chains were cut out and dissolved in $30 \%$ hydrogen peroxide. The radioactivity in each band was determined by adding liquid scintillation cocktail (Hyaromix by Yorktown) and counting in a Packard spectrometer.

\section{Carboxymethylceilulose Chromatography}

The constituent alpha alpha chains of collagen were separated by CM-cellulose chromatography essentially as described by Miller et al., 1971. The column $(1.5 \times 8 \mathrm{~cm}$ ) was equilibrated with the starting buffer $0.05 \mathrm{M}$ sodium acetate (pH 4.8) and after application of sample, eluted with a linear gradient of sodium chloride from 0 - 0.lil ir starting buffer, over a total volume of $400 \mathrm{ml}$. All cM-cellulose chromatography was carried out at $45^{\circ} \mathrm{C}$.

Four individual samples from each experimental group had to be pooied to obtain sufficient radioactive material (>200,000 cpm) for separation and quantitation oE collagen types by CM-cellulose chromatography. After dialyzing these pooled samples against starting buffer, urea 10.5 $g / m I)$ and 2-mercaptoethanol (2\%) were added. Each sample 
(cpm) in the $\alpha 2$ band and the $\alpha 1$ band (with and without reduction by mercaptoethanol) were used for the calculation of type I and type III collagen. Type I was represented by the cpm in $\alpha 1$ (without reduction) plus cpm in $\alpha 2$. The radioactivity in $\alpha 2$ was not affected by reduction. These values were multiplied by the appropriate dilution factor and expressed per ug. Of DNA in the total organ culture or cell culture system.

The radioactivity in $1 \mathrm{ml}$ aliquots of each fraction was plotted and the peaks representing the labelled collagen peptides $(\propto I[I], \propto 1[I I I], \propto 2)$ were quantitated by measuring the area under each peak with an electronic planimeter (Numonics Corp., Landsdale, PA.). Type I was quantitated from the combined area of the peaks for $\alpha 1$ and $\alpha 2$ chains. Type III was represented by the area of the $\alpha I$ (III) peak. Although these values could not be accurately expressed per ug of DNA, they were expressed as ratios of type III: type I and compared with the electrophoretic data similarIy expressed.

\section{Statistical Methods}

a) Mean: $\bar{x}=\frac{1}{n} \sum \dot{x}_{i}$

$$
\text { where } \begin{aligned}
\mathrm{n} & =\text { sample size } \\
\mathrm{x}_{i} & =\text { some of values for each sample }
\end{aligned}
$$

b) Standard deviation: $s=\sqrt{s^{2}}$

$$
\text { where } s^{2}=\frac{1}{n-1} \sum\left(x_{i}-\bar{x}\right)^{2}
$$


from the combined area of the peaks for $\alpha 1$ and $\alpha 2$ chains. Type III was represented by the area of tine $\alpha I$ (III) peak. Although these values could not be accurately expressed per ug of DNA, they were expressed as ratios of type III: type I and compared with the electrophoretic data similarly expressed.

\section{Statistical Methods}

a) Mean: $\bar{x}=\frac{1}{n} \sum x_{i}$

$$
\text { where } \mathrm{n}=\text { sample size }
$$

$x_{i}=$ some of values for each sample

b) Standard deviation: $\quad s=\sqrt{s^{2}}$

$$
\text { where } s^{2}=\frac{1}{n-1} \sum\left(x_{i}-\bar{x}\right)^{2}
$$

c) Standara error of the mean: $s_{x}=s / \sqrt{n}$

d) Student " $t$ " test: $\sqrt{\frac{\bar{x}_{1}-\bar{x}_{2}}{\left(N_{1}-1\right) s_{1}^{2}+\left(N_{2}-1\right) s_{2}^{2} \frac{N_{1}+N_{2}}{N_{1} N_{2}}}}$

ievel of significance was set at $P<.05$. 
e) Chi square test (For two independent samples):

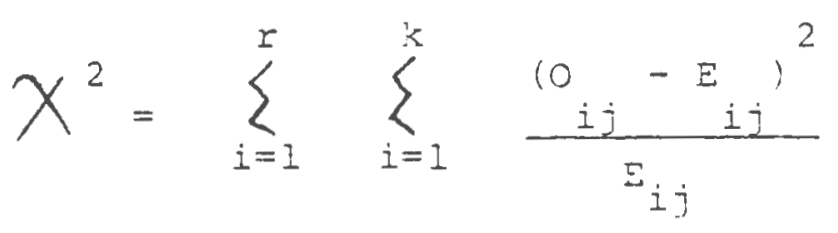

where $\mathrm{O}_{i j}=$ observed number of cases (explants categorized in the ith rov of jth column.

$E_{i j}=$ number of cases (explants) expected under $\mathrm{H}_{0}$ to be categorizea in ith row of jth column.

$$
\sum_{i=1}^{r} \sum_{j=1}^{k} \text { airects one to sum over all (r) rows }
$$

and all ( $k$ ) columns. The values of $X^{2}$ vielded by the above formula are distrihuted as chi square with df $=(r-1)(k-1)$, where $r=$ the number of rows and $k=$ the rumber of columns in the contingency table. To find the expected frequency of each cell ( $E_{i j}$ ), multiply the two marginal totals common to a particular cell, and then divide this product by the total number of cases (explants) N. 
RESULTS

This investigation used an established method of epinephrine infusion with thyroxine administration to produce macroscopic fiorous lesions in rabbit aorta (Fuller and Langner, 1970; Mickulicich and Oester, 1970; Lorenzen, 1962). Histopathological changes in the aorta included among other prominent features (Fuller et al., 1976): pronounced intimal thickening and the proliferation of a specialized cell type in the media. Vascular tissue for this investigation was obtasined from the medial region of the aorta which is composed predominantly of smooth muscle cells (Ross and Glomsett, 1973; Bierring and Kobayasi, 1963). There are no fibroblasts present in the media of mammalian arteries in contrast to the arteries of other species such as birds (French, 1966).

This investigation was conducted to examine the relationship between the proliferation of medial smooth muscle cells in culture and changes in the type specific synthesis of collagen related to atherogenesis. Eactors which influence this interrelationship appear to play a role in the development of the fibrous vascular plaque. This line of investigation would identify fundanental changes in the function of celis derived from arteriosclerotic smoot: muscle since the ratio of collagen type synthesized is controlled by gene expression. 


\title{
Vascular Smooth Muscle Cell Proliferation
}

\begin{abstract}
Medial explants $\left(1 \mathrm{~mm}^{2}\right.$ ) from corresponding regions $0 \leftleftarrows$ the thoracic aorta of normal and arteriosclerotic rabitis (same age) were incubated under the established concitions described in the Methods section. After 12 days of incubation the explants were observed and their growth was graded according to their appearance under the microscope at a magnification of 100x. Tive explants were attached in each $60 \mathrm{~mm}$ petri dish and each explant in the dish was graded. Five dishes were seeded frcm each aorta for a total of 25 explans per animal. Explants bearing a confluent matrix of smooth muscle cells at day 12 were designated: GOOD GROWIH. Those explants giving rise to fewer smooth muscle cells and lacking confluent orientation were designated as SOME GROWTH. NO GROWTH designated those explants with no evidence of cells migrating from the explant. Representatire photomicrographs of these categories are shown in Figure 1. The tabulated results of this evaliation are shown on Table $l$ and indicate the mean percentages of explants for each growth category. In the control group I4\% of the explants showed GOOD growth of smooth muscles celis; 58\% SOME growti and $28 \%$ No growth. In the arteriosclerotic groug $60 \%$ of the explants showed coop growth; $7 \%$ SOLE growth and $37 \frac{0}{3}$ No growth. Experiment 2, performed independently from Experiment $i$, used a sufficient number oi
\end{abstract}


FIGURE 1

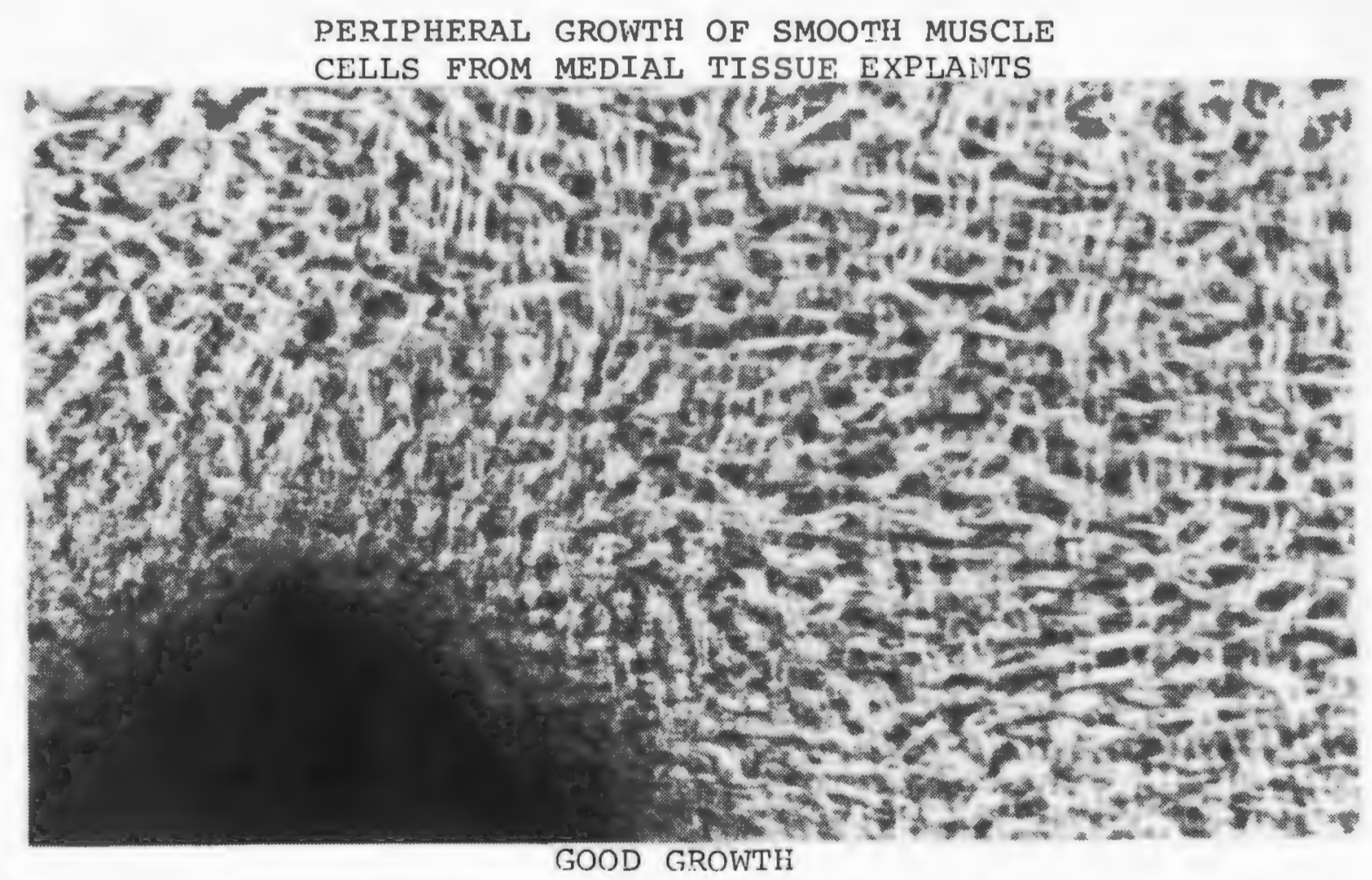

A Confluent Matrix of Cells (100x)

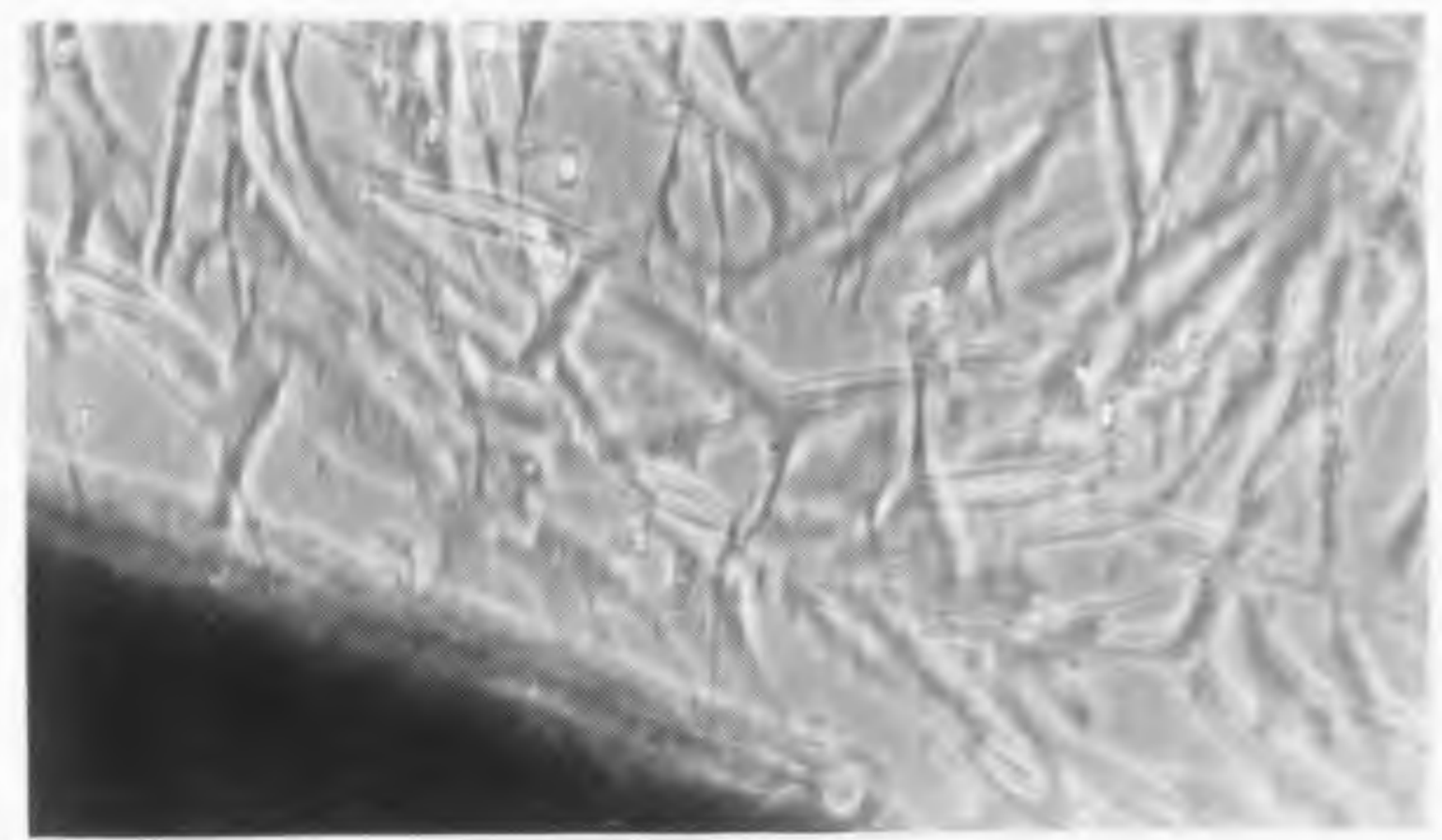

SQME, GROWTH

Significantly fewer cells, lacking confluent orientation (100X). 
animals in each group to permit statistical analysis by the Student "t" test. In Experiment 2 a Chi Square test for nonparametric data was used to test for significant difference between the control and arteriosclerotic groups regarding the absolute number of explants assigned to their aporopriate growth categories (e.g., GOOD, SOME, and NO growth). This analvsis also indicated significant differences between. control and arteriosclerotic in the GOOD and wo growth categories. There was no noticeable difference in morphology of the cells in each group.

Measurement of smooth muscle cell proliferation from the medial explants was determined for each petri disin on

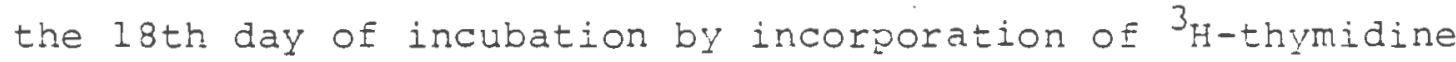
into TCA precipitable protein. The early indication of smooth muscle cell hyperplasia in arteriosclerotic tissue is further substantiated by the 2 -fold increase in 3 Hthymidine incorporation (CPM/ug DNA) during an 8-hour labeling period. The increase in DNA due to new cell growth was below the level of sensitivity of the colorimetric assay (Burton, 1956) and the DNA value 4.6 ug reflects, for the most part, the combined DNA of the Eive tissue explants in each culture cish.

\section{Collagen Heterogeneity in Primary Cultures of Rabbit Mediai Smooth Muscle Celis}

Thoracic medial smooth muscle from normal and arteriosclerotic rabbits was incubated with ${ }^{3}$ G-L proline in an 
TABLE 1

$$
\begin{gathered}
\text { ESTIMATION }^{a} \text { OF NEW CELL GRONTH } \\
\text { FROM MEDIAL EXPLANTS }{ }^{b}
\end{gathered}
$$

\begin{tabular}{|c|c|c|}
\hline Growtic & Control-( 2 animals) & Arteriosclerosis -13 \\
\hline Sood & $14 \%$ & $60 \%$ \\
\hline Some & 588 & $7 \%$ \\
\hline None & $28 \%$ & 378 \\
\hline
\end{tabular}

\section{Experiment 1}

\begin{tabular}{|c|c|c|}
\hline Growth ${ }^{\mathrm{c}}$ & Control-( 3 animals) & Arteriosclerotic- (4 animals) \\
\hline Good & $14 \% \pm 7$ & $56 \%+8^{e}$ \\
\hline Some & $48 \frac{8}{3} \pm 8$ & $32 \%+7$ \\
\hline None & $30 \% \pm 10$ & $128+4$ \\
\hline
\end{tabular}

Experiment $2^{\text {d }}$

a Observed under light microscope (100X) at day 12 of incubation $\left(37^{\circ} \mathrm{C}, 5 \mathrm{~g}_{2} / 95 \% \mathrm{Air}\right)$.

bhoracic aorta medial smooth muscle ( $1 \mathrm{~mm}^{2}$ ) 25 explants per rabbit and 5 explants per $60 \mathrm{~mm}$ dish.

Grade of growth: Good = confluent matrix of outgrowing celis Some = presence of growth but no confluent matrix of cells; None = no outgrowth detectable.

d

Experimert 2 conducted independently from Experiment 1.

Values are mean + S.E. and significantly difierent from control ( $0<.05$ sEudent "t" Eest). 
FIGURE 2

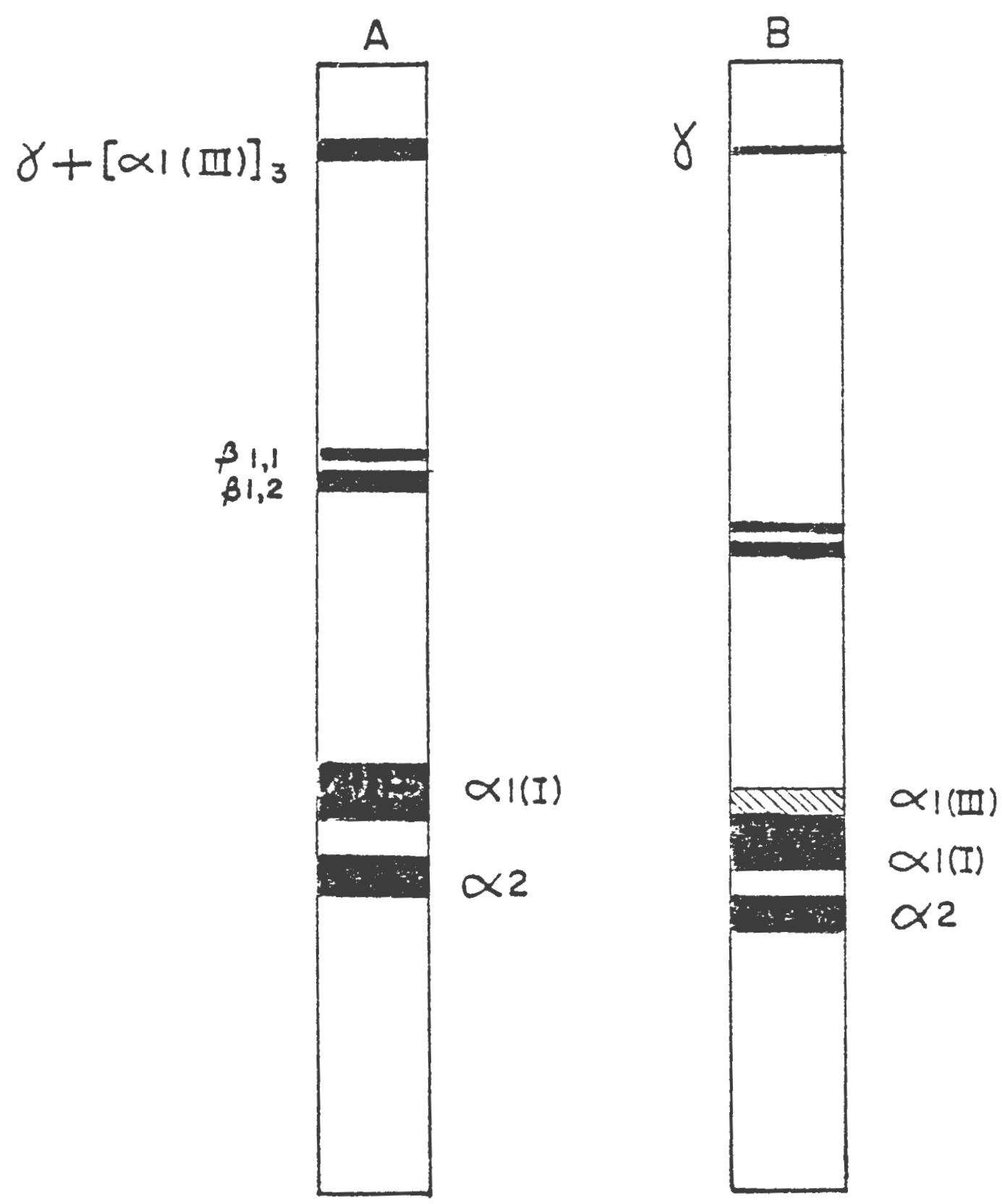

Yigration of Iype I and Type III Collagen Standazds or Polyacrylamide jels 3efore (A) and After Reduction ith 2,2 Yercaptoethanol (B). The slower pobility of $\alpha$ (III) is apparent. 
EFFECT OF MERCAPTOETHANOL AND BACTERIAL COLLAGENASE TREATMENT ON THE ELECTROPHORETIC MIGRATION OF ${ }^{3}$ H-PROLINE LABELLED COLLAGEN SYNTHESIZED IN CULTURE BY RABBIT VASCULAR SMOOTH MUSCLE

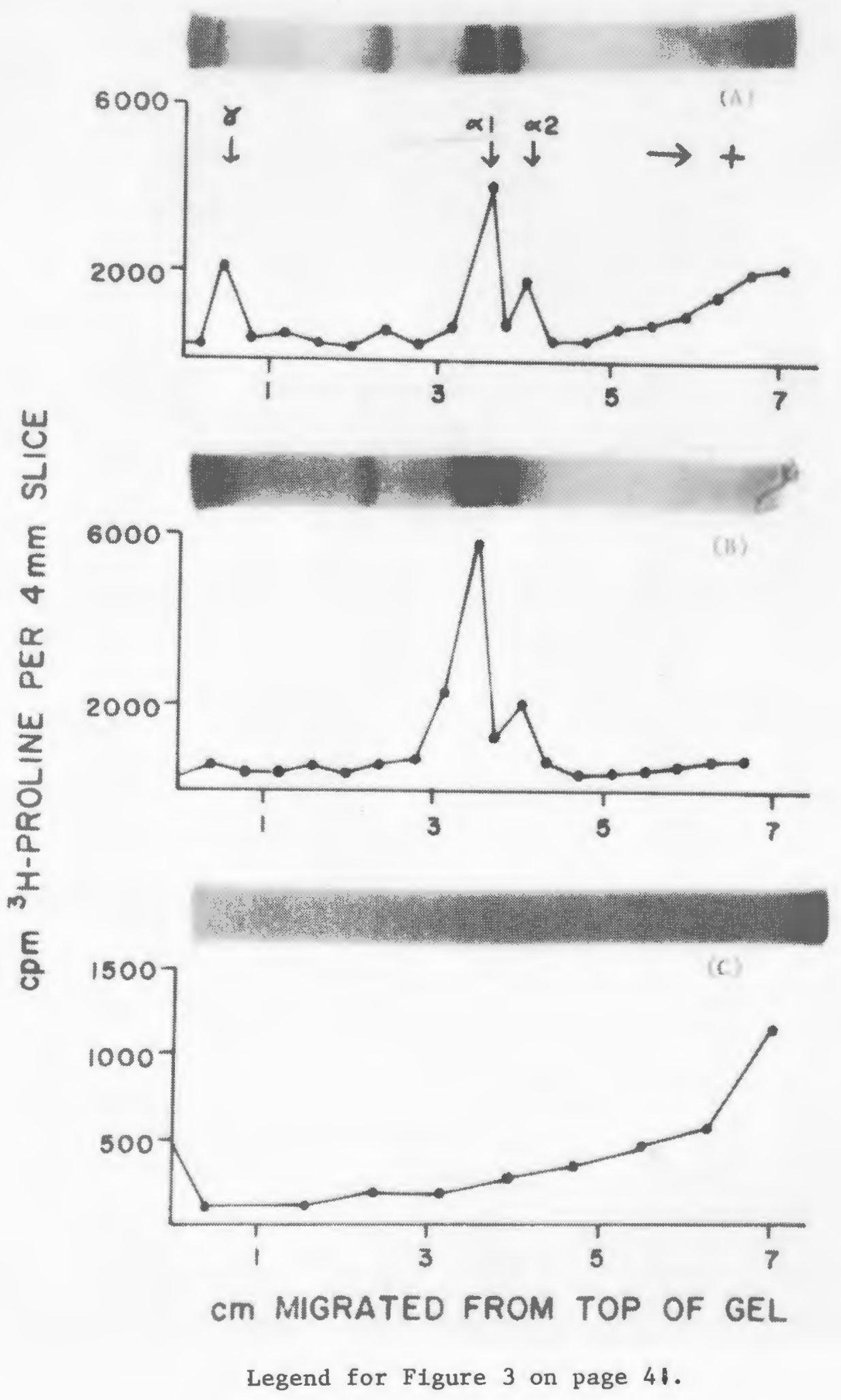


FIGURE 3. Effect of 2-Mercaptoethanol and Bacterial Collagenase Treatment of the Electrophoretic Migration of $3 \mathrm{H}$-Proline Lablelled collagen Synthesized in Culture by Rabbit Vascular Smooth Muscle.

Sample preparation and electrophoresis concitions described in the Methods. Each point represents the radioactivity in $4 \mathrm{~mm}$. slices of the gel.

Panel A: Unreduced sample of extracted collagen. Panel 3: Identical sample reduced with 2 z mercaptoethanol.

Panel C: Identical sample which was previously incubated with purified bacterial collagenase (protease-free). 
TABLE 2

PROLIFERATION OF SMOOTH MUSCLE CELLS FROM

EXPLANTS OF RABBIT THORACIC MEDIAL TISSUE ${ }^{a}$

\begin{tabular}{|c|c|c|c|c|}
\hline & $\mathrm{N}^{\mathrm{b}}$ & cpm ${ }^{3} \mathrm{H}-$ thymidine $\mathrm{c}^{\mathrm{C}}$ & Total DNA (ug) & CPM/Ug DNA \\
\hline CONIROL, & $(10)$ & $1661 \pm 571$ & $4.6 \pm 0.2$ & $364 \pm 125$ \\
\hline ARTERIOSCIEROTIC & $(12)$ & $3230 \pm 347$ & $4.6 \pm 0.2$ & $708 \pm 76^{\mathrm{f}}$ \\
\hline
\end{tabular}

a. Approximately 25 explans from each animal. Five $1 \mathrm{~mm}^{2}$ explants per dish (60 $\mathrm{x} 15 \mathrm{~min}$ ) At 18 th day of incubation as described in methods.

b. Number of dishes $(60 \times 15 \mathrm{~mm})$ in each group.

c. All cultures labeled with ${ }^{3}$ H-thymidine (10 uCi) for 12 hours.

d. per dish (explants plus cell layer) by the method of Burton, 1956.

e. Arteriosclerosis induced by epinephrine and thyroxin administration.

f. Mean \pm S.E.; significantly different from control ( $\rho<.05$ ) by student's "t" test. 
$\alpha$-region due to heat denaturation in the presence of $2 \frac{0}{3}$

2-mercaptoethanol. Panel (C) in Figure 3 shows loss in radioactivity due to prior incubation of the collagen preparation with purified clostridial collagenase (Peterkofsk $\because$ Diegelmann, 1971).

The increased radioactivity in the $\alpha-1$ region after reduction with mercaptoethanol indicates that control rabbit vascular smooth muscle synthesized 50\% type I collagen and 50\% type III coilagen (Table 3). Smooth muscle tissue from plaqued regions in the arteriosclerotic groups synthesized 63\% gype I collager and only $37 \%$ type III collagen. Increased synthesis of type I and III collagen in the crteriosclerotic group was significantly different from synthesis in the control group at $p<.05$ (Student "t" test). Inis could alternatively be expressed as a statistically significant change in the type I/type III ratio: 1.0 for the control group and 1.7 for the arteriosclerotic group. The synthesis of total radioactive type I and type III collagen, per ug of DNA, extracted from the primary cultures increased approximately two-fold in the arteriosclerotic group ccmpared to control.

\section{Collagen Heteroceneity and vascuiar}

\section{Smooth Muscle CeIIs in Culture}

Thoracic medial smooth muscle explants from romal and arteriosclerotic rabbits were placed in cuiture as described 
T'ABI,E 3

COLIAGEN SYNTHESIS IN ORGAN CUITURF:

BY RABBI'T MEDIAL SMOOTH MUSCLE:

CONT'ROL $(N=14)$

'Type I cpm/ug DNA

TYYе III cpm/ug DNA

Total

$$
\begin{aligned}
& 283 \pm 31 \\
& 254 \pm 25 \\
& 537 \pm 37
\end{aligned}
$$

ARTERIOSCLERO'TIC $(\mathrm{N}=13)$

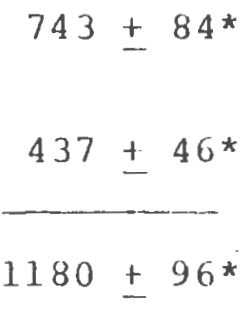

Aorta medial smonth muscle was incubated for 72 hours at $37^{\circ} \mathrm{C}$ in $2 \mathrm{ml}$ of DMEM containing 2,3-3 H-proline, BAPN, and ascorbate. Collagen types separated on polyacrylamide gels and quantitated radionetrically.

Values are the mean + S.I:

*Significantly different from control $(p<.05)$ student "t" test. 
in the Methods and the previous experiment. Daughter cells from these explants were propacated in DMEM containirg $20 \%$ fetal calf serum and antibiotics. These cells were subcultured approximately weekly into successively larger Elasks up to a confluent population of $5 \times 10^{6}$ cells per $75 \mathrm{~cm}^{2}$. This stage of growth represented 4 passages. At the end of this passage the cells were incubated for 24 hours in medium containing ${ }^{3} \mathrm{H}$-proline (2 uCi/ml), BAF:i (100 ug/ml) and ascorbate $(400 \mathrm{ug} / \mathrm{ml})$. Labelied collagen was extracted from the culture medium and DNA determined in the cell layer. Collagan types I and III were quantitated on gals according to the method previously ciescribed. Table 4 shows the relative and total amounts of type I and type III collagen synthesized by smooth muscle cells (SMC) at the end of their 4 th passage. Daughter cells from nomal aorta synthesized 6I type I and 39\% type III at this passage while daughter cells from arteriosclerotic medial tissue synthesized $78 \%$ type I and only $22 \frac{2}{3}$ type III collagen. Combired values for type I plus type III indicated that total collagen synthesis, although somewhat lower for the arteriosclerotic group (11, $174 \pm 1338 \mathrm{cpm} / \mathrm{ug}$ DNA versus 13,230 $\pm 1150 \mathrm{cpm} / \mathrm{ug}$ DNA) Nas not significantly different from cortrols at the $p<.05$ level.

\title{
Coilagen Suntiesis and Mge in Cuiture
}

\author{
Collagen type I and tyce III was measured in SMC cul- \\ tures at the ioth passage. Eigure 1 illustrates reiationshig
}


TABLE 4

COILAGEN SYNTHESIS IN CULTURE

BY RABBIT MEDIAT, SMOOTH MUSCLE CELISS

CONT ROL $(\mathrm{N}=12)$

Type I cpm/ug DNA

I'Ype III cpm/ug DNA

Total

\begin{tabular}{l}
$7963 \pm 499$ \\
$5049 \pm 823$ \\
\hline $13230 \pm 1150$
\end{tabular}

ARTERIOSCLEROTIC $(\mathrm{N}=15)$

$$
\begin{aligned}
& 8750 \pm 949 \\
& 2424 \pm 486^{\star} \\
& \hline 11174 \pm 1338
\end{aligned}
$$

Confluent cultures $\left(5 \times 10^{6}\right.$ cells/75 $\left.\mathrm{cm}^{2}\right)$ at the fourth passage. Incubated for 24 hours with 2,3-3I-proline in the presence of BAPI ascorbate and $10 \%$ fetal calf serum. Collagen types separated on polyacrylamide gels and quantitated radiometrically. Values are the mean $\pm \mathrm{S} . \mathrm{E}$.

*Significantly different from control ( $p<.05)$ student "t" test. 


\section{FIGURE 4}

EFFECT OF CLZTLRE PASSAGE NUIBER ON THE SYYTHESIS OF TYPE I AYD

TYPE III COLLAGEYS BY AORTA MEDIAI SMCOTH MUSCLE CELLS EROM

NORMAL ALD ARTERIOSCLERUTIC RABBITS

TYPE I $\square$

TYPE III EZA

$C=$ CONTROL

$A=$ ARTERIOSCLEROTIC
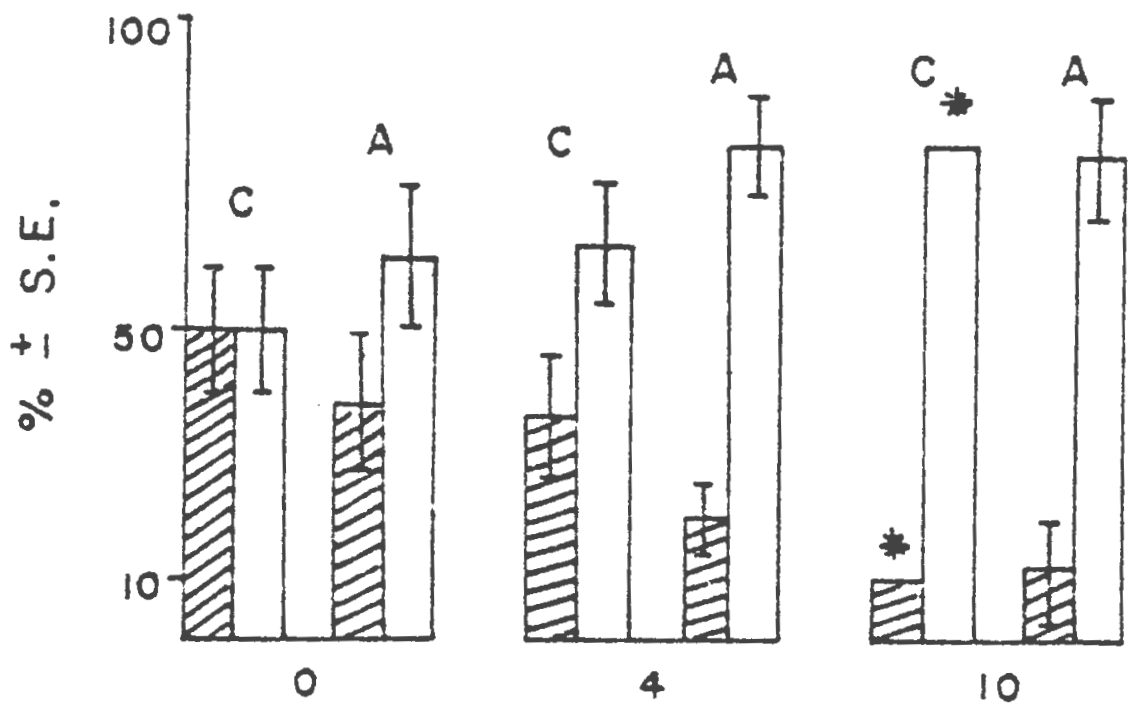

PASSAGE NUMBER

ALTERNATIVE REPRESENTATION QE TYPE III SYNTEESIS

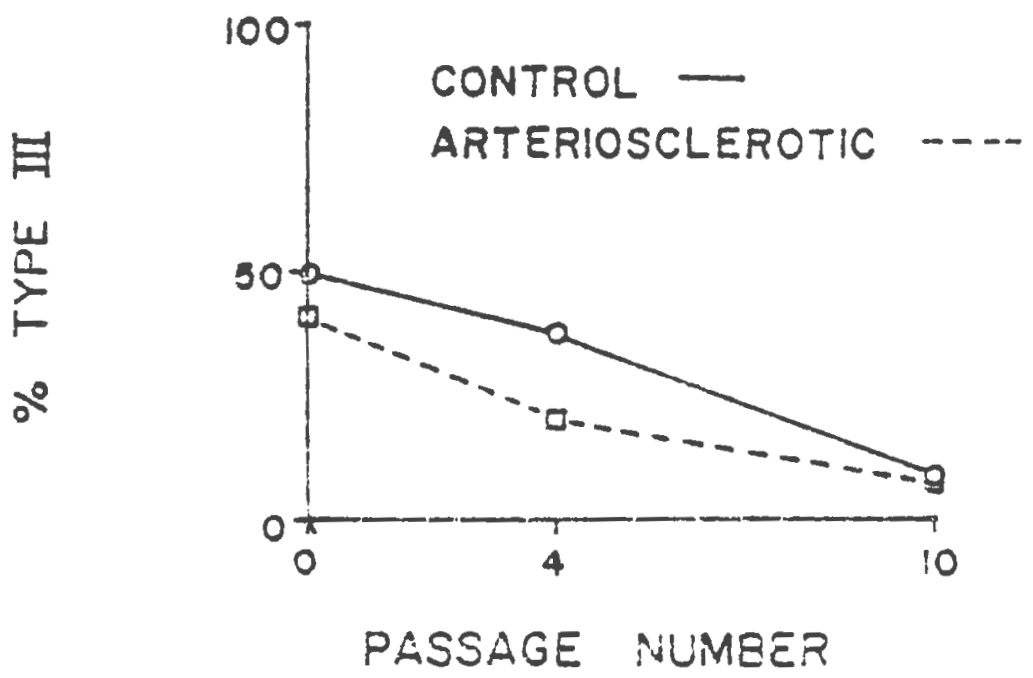


between age in culture and the relative synthesis of tyoe I and type III collagen. The cells from arteriosclerotic tissue make a larger proportion of type I (vs type III) compared to control at all passage levels. By the tenti passage type III synthesis represents no more than $10 \%$ of the collagen synthesized by cells grown from nomal or arteriosclerotic tissue. It was also apparent that by the tenth passage the celis in both groups were laying down less matrix compared to eariier passages which allows these celis to be more easily dissociated (enzymatic) upon subculturing, and to grow in confluent monolayers. In contrast, cells at early passages grow on top of one another, resembling hills and valleys, before reaching confluency.

\section{Collagen Heterogeneity by CMC-Chromatography}

The electrophroetic separation of labelled collagen types was developed for this study in order to permit analysis of individual cultures in sufficient numbers for statistical comparison. In order to validate ana confirm the data from this gel-electrophoresis system, pools were prepared from the primary organ culture system and also from the cell culture system to cbtain sufficient radioactive materiai to analyze collagen types on carboxymethylceilulose as described in the Methods.

$$
\text { Atter loading the reduced collagen extracts, the }
$$

collagen was eluted from the CMC with $400 \mathrm{mi}$ of sodium 
acetate buffer $(0.06 \mathrm{M}, \supseteq \mathrm{H} 4.8)$ over a continuous NaCl gradient $(0.0$ to $0.1 \mathrm{M})$ and $10 \mathrm{ml}$. Eractions were collected. The elution pattern is reflected by the radioactivity in aliquots from each fraction (Figure 5). Moving from left to right on the chromatogram in Figure 5 the three peaks after the gradient correspond to $\alpha I(I) ; \alpha I$ (III); and $\alpha 2$. In Eigure 5 (Organ Culture) the $\alpha$ (III) peak is high in relation to $\alpha I$ (I) for control tissue (upper panel) and is relatively low in relation to $\alpha_{l}(I)$ for the arteriosclerotic tissue group shown in the lower panel. As shown in Eigure 6, there is a similar decrease in relative anount of radioactivity in the $\alpha I$ (III) peak in the arteriosclerotic group (lower panel) compared to the control group shown in the top panel. The ratio of type III: type I collager was calculated from the total radioactivity found in each peak and is compared with the values obtained by gel electrophoresis (mable 5). For the organ culture system the ratios of collagen type III:I determined by either method were nearly identical. For the cell culture system both methods indicated an increase in type I collagen, relative to tipe III, for the arteriosclerotic group; however, the ratios of III:I calculated by cMC-chromatography were generalIy higher than those obtained by the electrophoretia method (Table 5). A significant difference in the results by the two anaiytical methods appeared only in the control cell culture group. This difference can be accounted for by the 
FIGURE 5

CMC-Chromatography of Labelled Collagen Synthesized In Organ Culture By Aorta Medial Swooth Muscle Eron Control And Arteriosclerotic Rabbits.

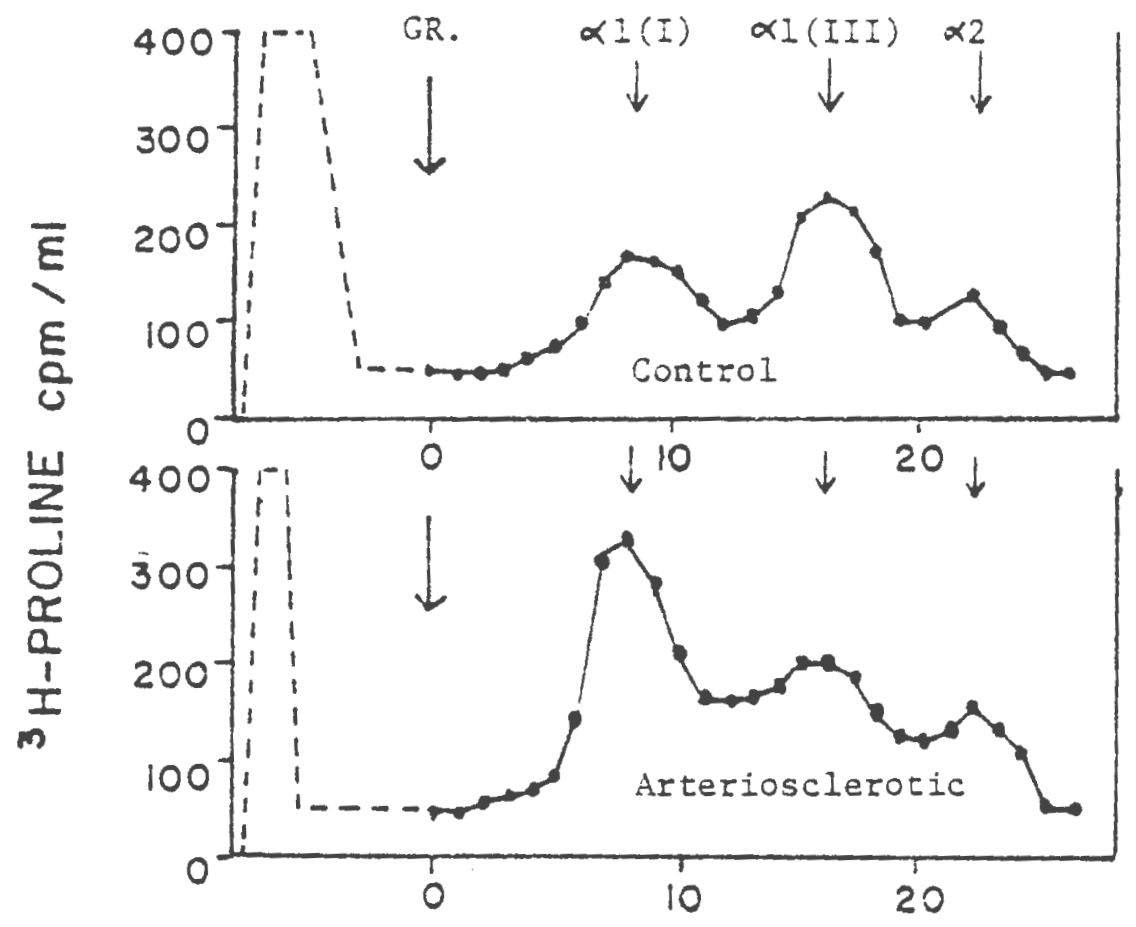

FRACTION NUMBER

Ico Parel: Contzol Graip. Zutzom Parel: Arcerioscleroltic Group. Collagen extracs szom normal and arceriosclerocic groups were prepared and applied to the colum as described in the Methcis. The bound collagen was eluced with a continLous sodiua chlozide gradient (0 - 0.1 M). The eiuate was collected in 20 m. Erecticns anc tise radioactivicy in I mi. aijquots of each ceunced. The position of elution of collagen $\alpha I(I), x I$ (III) and $\alpha 2$ siains ivas ustadisized by diromatography of salf skin colizgen staniszds. 
FICLRE 6

CAC-Chromatography of Labelled Collagen Synthesized by Cultured Smooth Muscle Cells Derived From Aorta Media of Control and Arteriosclerotic Rabbits.

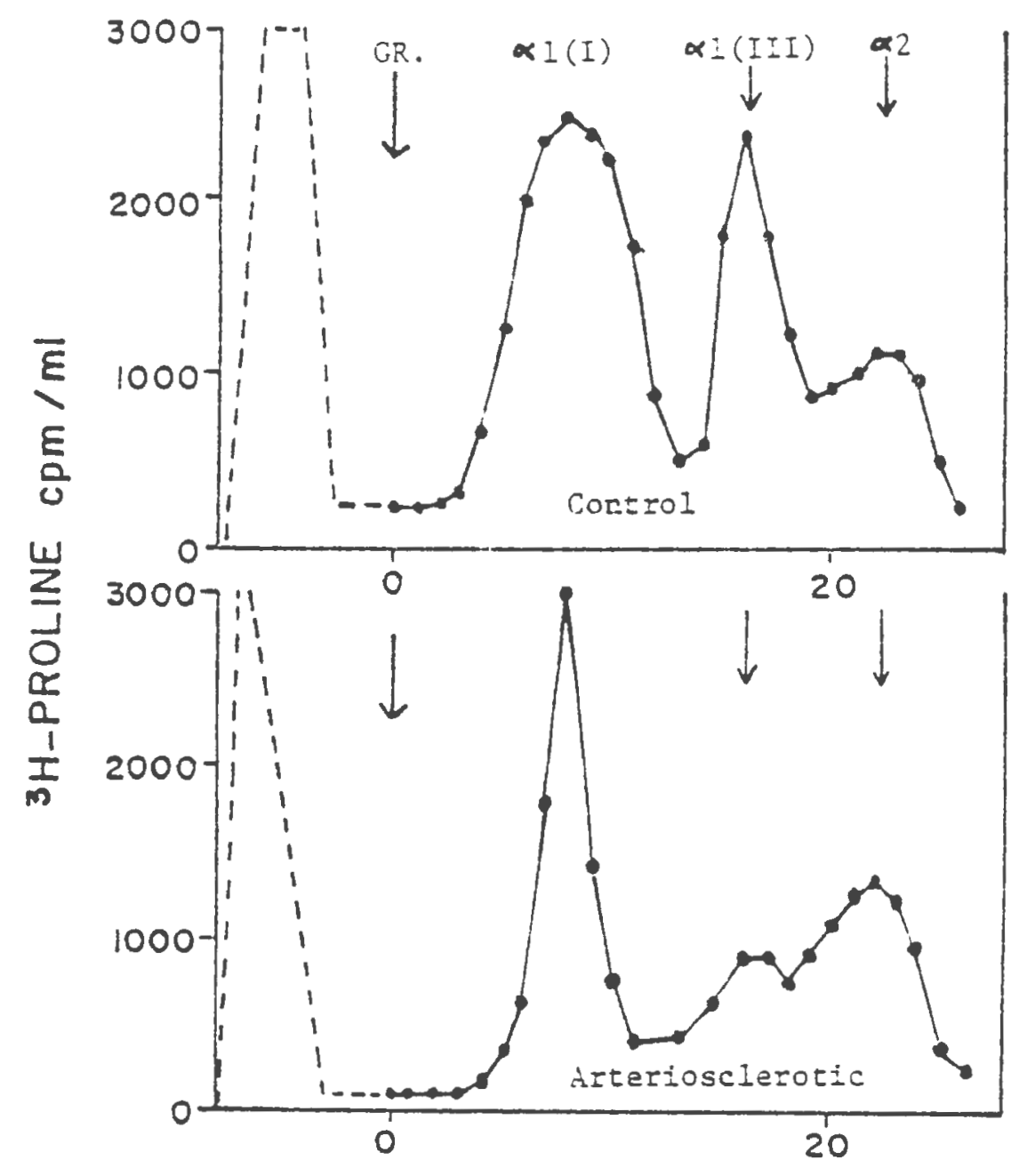

FRACTION NUMBER

Top Panel:Controi Group. 3octom Panel Arterioscierotic Group. Collagen extracts were prepared and appiied to the colurn as described in the Yethods. The bound collagen was eiuced itith a continucus sodium thioride gradient $(0-0.14)$. The eluate was collected in $10 \mathrm{ml}$. Fractions and the radioactivity in $I$ ml. alicuots of each counted. The position of elution of collagen $\alpha I(I), \alpha I$ (III) and $\alpha 2$ chains was establisined jy chromatography of calf skir collagen standaris. 
TABLE 5

COMPARISON OF ELECTROPHORETIC AND CHROMATOGRAPHIC RESULTS

FOR JUHE SYNTHESIS OF TYPE I AND TYPE III COLIAGENS

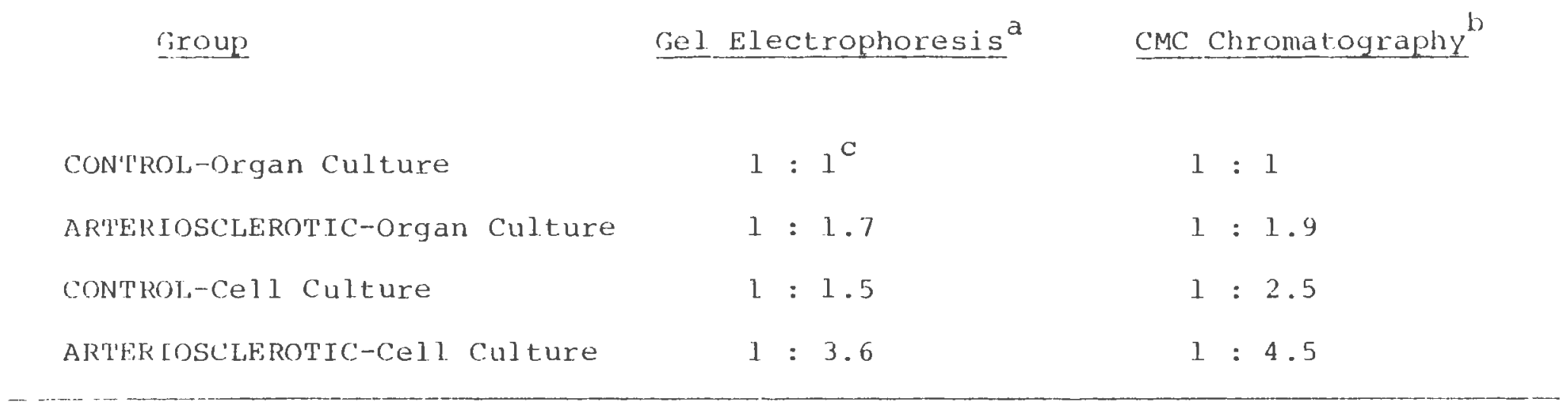

a

Mean values from Tables 3 and 4 (cpm/ug DNA).

Latios computed from areas under the peaks of elution profile for länelled collagenous proteins.

C Ratios represent amount of type III: I collagen. 
unavoidable variability in the individual ratios for the samples that were pooled for CMC-chromatography. Except for the above-mentioned group the variability between the two methods was no more than 108. 


\section{DISCUSSION}

Intravenous injections of epineohrine in the rabbit produces arteriosclerotic lesions, which are aggravated by the simultaneous administration of L-thyroxine. The major alterations observed in rabbit arteriosclerosis induced by epinephrine plus thyroxine occurs in the smooth muscle cells and the elastic fibers of the aorta, similar to the lesions seen in arteriosclerosis of man (Kobayasi, 1969; Daoud et al., 1964). Histological examination reveals structural changes in the smooth muscle cells such as cyctic protrusions of the sarcoplasm, vacuole formation and condensation of myofilaments. These changes are accompanied by fragmentation degeneration of the elastic fibers. It has been suggested that factors, associated with various forms of vascular injury, influence the fundamental structure and function of the mediai smooth muscle (Ross and Glomset, 1973). It has been proposed that medial smooth cells, responding to intimal injury, migrate into the intima and begin to proliferate establishing a colony resembling a benign neoplasm which synthesize a gerercus amount of collagen (Benditt, 1977). Mccuilagh and Belian (1975) anazyzed pepsin extracted collagen Erom a pooled sample ce intimal plaques from 3 atherosclerotic human aortas. They reported

a marked increase in the ratio of type I to type III collagen, 
compared to that in the nonarteriosclerotic aortic nedia. In their procedure, less than 50\% of human aorta collagen was recovered in the extracts and subsequently characterized. No studies have reported the relative rate of synthesis of type I and II collagen in diseased vascular tissue. The data described in this investigation estabiishes that a significantly greater population of smooth muscle cells migrate out of the medial explants dissected from tissue subjected to an atherogenic condition compared to medial explants from the nonarteriosclerotic group. This enhanced outgrowth from tissue explants supports the current hypothesis that in atherogenesis modified smooth muscle cells in the medial layer migrate from the media, through the internal elastic lamella and into the intimal region. Conditioned media from rapidly growing medial explants when transferred to slower growing explants did not stimulate migration of cells from slower growing explants. This observation would rule out the possibility that the rapidly proliferating and migrating modified smooth muscle cells liberate soluble growth promoting factors. However, there may be a higher concentration of platelet factors, insulin or lipoproteins, due to increased vascular permeability, in the explants of arterioscierotic tissue wrich could erhance SMC outgrowth (Ross and Glomset, 1973; Eriedman et al., I975). Also the accumulation of collagen, elastin and mucopolysaccharides in arterłosclerntic tissue may present an extraceliular matrix more supportive of cellular outgrowth and migration. 
Another explanation for the more rapid outgrowth could be based on decreased protein degradation and higher metabolic activity in the tissue explant. The first evidence that decreased protein degradation may contribute to rapid growth of mamalian tissues cane from studies of work induced hypertrophy of skeletal muscles (foldberg et al., 1975). Similar reports exist in the literature correlating decreased proteolysis with rapid compensatory growth in other tissues (Scornik, 1972). Current understanding of the relationship between DNA synthesis and protein synthesis leads to the conclusion that, over an extended period of time, DNA synthesis must be dependent on protein synthesis. However, it is known that the high dose of thyroid hormone used for the experimental model in this study produces generalized weight loss and muscle atrophy. Under such conditions total protein degradation should exceed total protein synthesis. Therefore, rapid outgrowth of medial explants from arteriosclerotic vessels appears to be the result of some phenomenon which specifically stimulates a latent growth property in vascular smooth muscle cells.

As discussed above, enhanced cell growth in the arteriosclerotic group was observed at the I2th day of incubation. At the 18th day in cliture H-thymidine incorporation into DNA indicated that smooth muscle cells in the arterioscierotic group were still proliferating faster than 
SMC Erom control explants. Stimulatory factors present in the tissue explant could have been responsible for promoting early outgrowth, but it is unikely that they are still influencing new DNA synthesis at the l8th day in culture in the presence of Eresh media. This data is also supported by the consistent finding that it took comparatively longer to propagate smooth muscle cells in the control group to their fourth passage. Increased mitotic activity is a common characteristic of transformed or the differentiated cells. The ability of SMC from arteriosclerotic tissue to adapt to and proliferate more rapidly in vitro is suggestive that they have undergone fundamental changes and could be considered analogous to those cells comprising the benign smooth muscle tumor described by Moss and Benditt (1975) and Rounds et al. (1975).

Morphologically, SMC grown from normal tissue and arteriosclerotic tissue were indistinguishable and they both exhibited typical features such as abundant myofilaments and surface vesicles. These observations agree with those of Ross (1971) who has used identical culture methods. Further characterization of these cells was not within the scope of this study, but has been explored by other investigators (Mauger et al., 1975; Kines and Brandt, 1976) who obtained SMC by the same technique. However, it was observed in this study that SMC from normal tissue enter senescence sooner than SMC from arterioscierotic tissue. 
Senescence was accompanied by pronounced vacuolization, loss of cellular definition, and loss of proliferative activity.

A portion (50 $\mathrm{mg}$ ) of Ereshly dissected medial smooth muscle was placed in an organ culture system as described in the Methods. Preliminary experiments indicated that 50 $\mathrm{uCi} / \mathrm{ml}$ of $2,3-{ }^{3} \mathrm{H}-\mathrm{L}$ proline and a 72 -hour incubation were necessary to obtain adeguate quantities of newly synthesized soluble collagen of high specific activity for resolution on polyacrylamide gels. The use of BAPN prevents crosslinking of collagen molecules and assures complete extraction of the labelled collagen. These primary explant cultures maintain viability for prolonged periods based on a report by Fritz et al. (1975) that protein and DNA synthetic activity persist for up to 9 days in aortic medial explants that were maintained under similar conditions. It was observed that primary cultures derived from control rabit vascular smootin muscle synthesized approximately 50\% type I collagen and 50\% tyoe III collagen (Table 3). Analogous tissue in the arteriosclerotic group synthesized 63\% type I collagen and only $37 \%$ type III. Gay et aI. (1975) by immunofluorescert techniques have shown that type III occurs in human aorta, to the exclusion of type I collagen, in the area immediateiy underiying the internal elastic lamelia. Type III concentration in the media, relative to type I, diminishes toward the adventitia. McCullacin and Belian (1975) reported $70 \%$ type I and $30 \%$ type III in a 
nondiseased normal human aorta and a shift in the extracted collagen ratio Eavoring type $I$ in arteriosclerosis. The data reported here confirms that observation. There was considerable sample variation in both experimentai groups with regard to the absolute amount collagen synthesis; however, this variation was reduced when the values were expressed per ug. of DNA. Fritz et al. (1975) reported that in a similar system there was a high degree of correlation between protein and DNA synthesis. The fact that both types of collagen increased in the arteriosclerotic groups, compared to controls, suggests a general activation of the pathway for collagen synthesis specific for type I synthesis in agreement with previous findings (Fuller et al., 1976).

The daughter cells growing in the tissue culture system proved to be more efficient in producing labeiled collagen. In these cultures as much as $20 \%$ of the radioactive protein released into the medium was collagenase digestible; nowever, an average of about $10 \%$ was collagenase digestible. It was still necessary to add carrier collagen to the extracted ${ }^{3} \mathrm{H}$-proline labelled collagen in order to visualize the characteristic collagen bands a fter separation on polyacrylamide gels stained with coomassie blue. The total disappearance of radioactivity from the collagen protein bands by prior treatment oi the sample with purified clostridiai collagenase (protease-Éree) consistentiy confirmed the identity of these characteristic bands. 
Daughter cells derived from control aorta were synthesizing $60 \%$ type I and $40 \%$ type III collagen at the end of their 4th passage (Table 4). Cells derived from arteriosclerotic aorta at the same passage and density $\left(5 \times 10^{6} ;\right.$ $75 \mathrm{~cm}^{2}$ ) synthesized $80 \%$ type I and 208 type III collagen The synthesis of collagen type I/ug. DNA was the same in each group. The synthesis of type III was significantly $(p<0.05)$ decreased in the arteriosclerotic groupl however, this decrease was not enough to produce a significant $(p<0.05)$ difference in total collagen synthesized by the experimental group of smooth muscle cells. The significant decrease in type III synthesis was confinmed by CMCchromatography (Eigure 5). As mentioned in the Results section there was variation in the ratio of collagen types determined by the different analytical methods for the cell culture system. However, there was no observed disagreement in the ratio of these types synthesized by the organ culture system. This may be due to the differential influences in each method by small arounts of aberrant or unnatural forms of collagen (i.e. $[\alpha I(I)]$ trimer) that could be intrinsic to the proliferating cell culture system of daughter cells. No radioactivity above background could be cetected in the gel regions corresponding to the dimer forms of collagen $\left(\beta_{1,1}\right.$ or $\left.\beta_{1,2}\right)$ at this level of BAPN supplement. It was determined by zreliminary experiments that twice the normal concentration of BAPN was required 
to inhibit cross-linking of collagen $\alpha$-chains. These cell lines were reported to be exceptionally rich in lysyl oxidase activity (Herbert Kagan, personal communication). Rhoads and Miller (1978) have recently isolated and characterized two new types of collagen chains designated $A$ and $B$. Based on their composition both chains resemble collagen chains isolated from basement membrane. McCullagh and Sweet (1978) have incicated that smooth muscle cells in culture synthesize collagen $A$ and $B$ chains which are minor components of the cellular expression of collagen synthesis $(<2 \%)$ (Brown et al., 1978). Thus, these chains are not synthesized in large enough quantity to interfere in the detection of a significant shift in the ratio of type I and type III collagen. However, they may account for some of the variability between the electrophoretic and chromatographic results, since the $\mathrm{A}$ chain migrates in the same position as the $\alpha_{i}$-chain on sodium dodecyl-sulfate polyacrylamide gels.

The calculation of the relative ratios of collagen types as quantitated here could be carried out by several means. In this investigation the ratio of the radioactivity for $\alpha 1: \alpha 2$ varied Erom 1.8 to 2.3 and was considered to be within acceptable limits of sensitivity for the analytical techniques. Type I collagen was quantitated by measuring the total coms in the $\alpha 1$ band plus and $\alpha 2$ band in unreduced samples. However, if one were to strictly adhere to the 
theory that $\alpha 1: \alpha 2$ must be in a $2: 1$ ratio then it is possible that in some samples as much as $10 \%$ type I trimer [ $\alpha$ I II) $]_{3}$ could be present. It has been shown that when chick choncirccytes are grown in the presence of BUdR for a few days, collagen biosynthesis will switch from cartilage specific type II collagen $[\alpha](I I)]_{3}$ to a mixture of type I collagen $[\alpha](I)]_{2} \alpha^{2}$ and type I trimer $\left.[\alpha](I)\right]_{3}$ (Mayne et al., 1975). It has been suggested that the formation of type I trimer is associated with the shift in gene expression responsible for a shange in the type of collagen produced (Mayne et al., 1976). It is evident from this study that atherogenic factors that modify the growth characteristics of vascular smooth muscle cells also modify the gene expression for different collagen types.

By the tenth passage in culture sMC derived from both control and arteriosclerotic groups were synthesizing exclusively tyoe I collagen. Considerable difficulty ras experienced in carrying SMC in the control group to the loth passage, due to an apparent decrease in flating efficieroy and growth rate, suggestive of senescence. Coilagen heterogeneity was measured in only two flasks of control celis at the loti passige and found to be about $90 \%$ type I for each. The effect of time in culture on the synthesis of type I coliagen can be explained by what has been reported regarding "colizgen switching." Cellular senescence appears to be delayed in the arteriosclerotic cell group, which is 
consistent with the other indication of dedifferentiation mentioned above. The SMC in the control group proliferate at a slower rate which suggests that their growth requirements are more stringent than those for the cells in the arteriosclerotic group. The Sil in the control group may be more dependent than SMC in the arteriosclerotic group, on species-specific growth factors not present in the heterologous, heat inactivated, fetal calf serum. A decrease in the requirement for multiplication stimulating Eactors in serum has been observed in viral transformed chick embryo fibroblasts (Smith et al., 1971). These types of factors could modulate the onset of senescence. 


\section{CONCLUSINNS}

1). The migration of smooth muscle cells from aorta extracts is more rapid in tissue derived from arteriosclerotic lesions than from control aorta. This supports the hypothesis that there is a greater population of these ceils with enhanced migratory potential in the arteriosclerotic lesions. It is suggested that these modified smooth muscle celis would similarly be more attracted to the injured intima in the in vivo situation.

2). Daughter cells from arteriosclerotic smooth muscie proliferate in cuiture at a higher rate than their counterparts from normal tissue. These modified smooth muscle cells resemble transformed cells which are generally considered to have exaggerated or higher growth kinetics than untransformed cells.

3) The population of smooth muscle cells derived from arteriosclerotic aortas contain cells which are phenotypically different fror smooth muscle ceils from control aorta with respect to collagen heterogeneity. This disease related change in collagen hetaroGeneity has been reported in vivo and now has been shown to be characteristic in the genome of daughter cells maintained in vitro. 
4). Derepression of collagen type I synthesis has been linked with cellular processes associated with aging, scars and transformation as observed for chondrocytes in culture. It appears that arteriosclerosis enhances this derepression process for vascular smooth muscle cells permitting the accumulation of fibrous collagen components resembling scar tissues which become fibrous vascular plaques.

5). These data also support a clonal selection hypothesis. If a cell only synthesizes one type of collagen at a time, tissues synthesizing more than one type of collagen have more than one, type-specific population, of collagen producing cells. The numerous population doublings and subsequent subculturing procedures may favor for one subpopulation of SMC (e.g. type I collagen producing) and not the other subpopulation (e.g. type II collagen producing). 


\section{REFERENCES}

Abraham, P.A., Smith, D.W. and Carnes, W.H.: Biosynthesis of lysine derived crosslinks in aortic cell culture. Biochem. Biophys. Res. Comm. 67: 723, 1975.

Balazs, E.A.: "The Chemistry and Molecular Biology of the Intercellular Matrix," Vols. 1-3, Academic Press, N.Y., 1970.

Barnes, M.J., Martin, L.F. and Levene, C.I.: Synthesis of collagen types I and III by pig medial smooth muscle in culture. Biochem. Biophys. Res. Comm., 70: 339, 1976.

Bates, S.R. and Wissler, R.W.: Effect of hyperlipemic serum on cholesterol accumulation in monkey aortic medial cells. Biochim. Biophys. Acta, 450: 78, 1976.

Benditt, E.P. and Benditt, J.M.: Evidence for a monoclondl origin of human atherosclerotic plaques. proc. Natl. Acad. SCi. USA, 70: 1753, 1973.

Benditt, E.P.: The origin of atherosclerosis. Scientific American, 236: 74, 1977 .

Bierring, F. and Kobayasi, T.: Electron microscopy of the normal rabbit aorta. Acta Path. Microbiol. Scandinav., 57: $154,1963$.

Boas, N.F.: Method for the determination of hexosamines in tissue. J. Biol. Chem., 204: 553, 1953.

Bornstein, P. and Ehrlich, H.P.: Biology of Fibroblasts. Kulonen and Pikkaraninen (eds.) pp. 231-2, Academic Press, N.Y., 1973.

Brown, R.A., Shuttleworth, C.A., Weiss, J.B.: Three new chains of collagen from a nonbasement membrane source. Biochem. and Biophys. Res. Comm., 80: 866, 1978.

Burton, K.: A study of the conditions and mechanisms of the diphenylamine reaction for the colorimetric estimation of deoxyribose. Biochem. J., 62: 315, 1956.

Chung, E., Keele, E.M. and Miller, E.J.: Isolation and characteriziation of the cyanogen bromide peptides from the 1 (III) chain of human collagen. Biochemistry, 13: 3459 , 1974.

Crossley, H.L., Johnson, A.R., Maurer, K.K., Wood, U.L. and Fuller, G.C.: Aortic prolire hydroxylase in hypoxia induced arteriosclerosis in rabbits. Life sciences, 11: 869, 1972. 
Daoud, A., Jarmolych, J., Zumbo, H., Fani, K. and Florentine, R.: Preatheroma- A phase of corcnary atherosclerosis in man. Exp. et Mol. Path., 3: 475, 1964.

Engel, U.R.: Glycosaminoglycans in the aorta of several animal species. Atherosclerosis, 13: 45, 1971.

Epstein, E.H.: 1 (III) 3 human skin collagen: Release by pepsin digestion and preponderance in fetal life. J. Biol. Chem. 249: 3225, 1974 .

Eostein, E.H. and Munderloh, N.H.: Isolation and characterization of CriBr peptides of human l(III) 3 collagen and tissue distribution of 1 (I) 2 and 1 (III) 3 collagens. J. Biol.

Chem., 250: 9304,1975 .

Federoff, S.: Tissue culture technology applicable to arterial mesenchyme, In Advances in Experimental Medicine and Biology eds. Wagner and Clarkson, Vol 43, p. 247 , Plenum Press, N.Y., 1974 .

Fowler, S., Shio, H. and wolinsky, H.: Subcellular fractionation and morphology of calf aortic smooth muscle cells. J. of Cell Biology, 75: 166, 1977.

French, J.E.: Atherosclerosis in relation to the structure and function of the arterial intima, with special reference to the endotheiium. Int. Rev. of Exp. Pathol., 5: 253, 1966.

Friedman, R.J., Stemerman, M.B., spaet, T.H., Moore, S. and Goulde, J.: The effect of thrombocytocenia on arteriosclerotic plaque formation. Fedn. Proc., 35: Abst. ․ 207, 1976.

Fritz, K.E., Augustyn, J.Y., Peters, T. Jr., Jarmolych, J. and Daoud, A.S.: Protein synthesis and its relation to DNA synthesis in aortic explants. Atherosclerosis 23: 177, 1976 .

Fuller, G.C. and Langner, R.O.: Elevation of aortic proline hydroxylase- A biochemical defect in experimental arteriosclerosis. Science, 168: $987,1970$.

Fuller, G.C., Miller, E., Farber, T. and Vanloon, E.: Aortic connective tissue changes in miniature pigs fed a lipid-rich diet. Connective Tissue Research, l: 217, 1972.

Fuller, G.C. and Crossley, H.L.: Proline hydroxylase in injury induced arteriosclerosis In Proc. II International Diabetes Sympos. (Curacao, N.A.) H. Cole, editor, Ecademic Press, V.Y., pp. 111-116, 1973.

Fuller, G.C., Matoney, A.L., Eisher, 7.0., Fausto, N. and Cardinale, G.J.: Increased collacen synthesis and the kinetic characteristics of prolyl hydroxylase in tissues of rabbits with experimental arteriosclerosis. Atherosclerosos, 24: 483,1976 . 
Gay, S., Fietzek, P.P., Remberger, K., Eder, M. and Kuhn, K.: Liver cirrhosis- Immunofiorescence and biochemical studies demonstrate two types of collagen. Klin. rochenscher., 53: 205,1975 .

Geer, J.C. and Haust, M.D.: Identification of cells in other sclerotic lesions: A historical review. Monogr. Atheroscler., 2.: 19,1972 .

Goldberg, A.L., Etlinger, J.D., Goldspink, D.F., and Jablecki, C.: Skeletal muscle development following exercise. Med. Sci. Sports, 7: 185, 1975.

Goldberg, B., Taubman, M.B. and Radin, A.: Procollagen peptidase-Its mode of action on native substrate. Cel1, 4: 45, 1975 .

Hartman, J.D.: Structural changes within the media of coronary arteries related to intimal thickening. Am. J. of Pathology, 89: 13, 1977 .

Haust, M.D., More, R.H. and Movat, H.z.: The role of smooth muscle cells in fibrogenesis of arteriosclerosis. Am. J. of Path., 37: 377, 1960 .

Helin, P. and Lorenzen, I.: Atherosclerosis in the rabbit induced by systemic hypoxia. Angiology, 20: 1, 1969.

Helin, P., Gelin, P. and Lorenzen, I.: The aortic glycosaminoglycans in arteriosclerosis induced by systemic hypoxia. Atherosclerosis, 12: 235, 1970.

Helin, P., Lorenzen, I., Garbarsch, C. and Matthiessen, M.E.: Repair in arterial tissue. Circulation Res., 29: 542, 1971.

Helin, P., Lorenzen, I., Garbarsch, C. and Matthiessen, M.E.: Repair processes in vascular connective tissue following experimental injury. Angiology, 23: 183, 1972 .

Hoffman, A.S.: In "Biomaterials," A.I. Bement, Jr., ed., pp. 285-312. University of washington press, seattle, 1971.

Holtzer, H. and Abbott, J.: Oscillations of the chdrogenic phenotype in vitro. In "The stability of the Differentiated State," H. Jrsprung, ed., pp. 1-16. Springer, Berlin, 1968.

Hughes, J., Herion, F., Nusgens, B. and Lapiere, Ch.M.: In vitro studies on platelet-collagen interactions. Thomb. Res., g: $223,1976$.

Janoff, A.: Elastolvtic activity in neutrophil granuiocyte extracts. Ser. Haematol., 3: 96, 1970. 
Kajikawa, K., Nakanishi, I., Hori, I.: Electron microscopic observations on connective tissue using ruthenium rea staining. J. Electronmicroscopy, 19: 347, 1970.

Kimes, B.W. and Brandt, B.L.: Characterization of two putative smooth muscle cell lines from rat thoracic aorta. Exo. Cell Res., 98: 349, 1976.

Knieriem, H.J., KaO, V.C.Y. and Vissler, R.W.: Demonstration of smooth muscle cells in bovine arteriosclerosis. J. Athero. Res., 8: 125,1968 .

Kobayasi, T.: Fine structure of arteriosclerosis induced in rabbit aorta by epinephrine and thyroxine. Acta path. Microbiol. Scandinav., 76: 193, 1969.

Kokubu, $x$. and Pollak, $0 . \mathrm{J}$. : In vitro cultures of aortic cells of untreated and of cholesterol-fed rabbits. J. Atheroscler. Res., 1: 229, 1961 .

Kumar, V., Berenson, G.S., Ruiz, H., Dalferes, E.R. and Strong, J.P.: Acid muscopholysaccharides in human aorta, Part 2 (Variation with atherosclerotic involvement). J. Atheroscler. Res. 7: 573, 1967 .

Langner, R.O. and Fuller, G.C.: Collagen synthesis in thoracic aortas of rabbits with epinephrine-thyroxine induced arteriosclerosis. Atherosclerosis, 17: 463, 1973.

Lapiere, C.M., Lenaiers, A. and Kohn, L.D.: Procollagen peptidase. Proc. Nat. Acad. Sci., 68: 3054, 1971.

Lapiere, C.M., Husgens, B. and Pierard, G.: Interaction between collagen type I and III in conditioning bundle organization. Connective Tissue Res., 5: 21, 1977.

Layman, D.L. and Titus, J.L.: Synthesis of type I collagen by human smooth muscle cells in vitro. Lab. Investig., 33: $103,1975$.

Legrand, Y., Caen, J., Booyse, F., Rafelson, M., Robert, B. and Robert, L.: Studies on a human platelet protease with elastolytic activity. Biochim. Biopiys. Acta, 309: 406, 1973.

Levene, C.I. and Poole, J.C.F.: The collagen content of the normal and atherosclerotic human aortic intime. Brit. J. OE Pathol., 43; 469, 1962 .

Lorenzen, I.: Alteration in acid mucopolysaccharides and collagen of rabbit aorta related to age of epinephrinethyroxine induced arteriosclerotic lesions. Acta Endocrinol., 39: 615,1962 . 
Marzulio, G. and Lash, J.: Control of phenotypic expression in cultured chondrocytes: Investigation on the mechanism. Develop. Biol., 22: 638, 1970 .

Mathews, :.B.: The interaction of collagen and acid mucopolysaccharides. Biochem. J., 96: 710, 1965.

Mauger, J.P., Worcel, M., Tassin, J. and Coutois, Y.: Contractility of smooth muscle cells of rabbit aorta in tissue culture. Nature, 225: 337, 1975.

Mayne, R., Vail, M., Mayne, p. and Miller, E.: Changes in type of collagen synthesized as clones of chick chondrocytes grow and eventually lose division capacity. PNAS., 73: 1674,1976 .

Mayne, R., Vail, M. and Miller, E.: Analysis of changes in collagen biosynthesis that occurs when chick condrocytes are grown in 5-bromo-2'-deoxyuridine. Proc. Nat. Acad. Sci., 72; 4511, 1975 .

McCullagh, K.G., Deroutte, S. and Robert, L.: Studies on elephant aortic elastic tissue Dart II. Amino acid analysis, structural glycoproteins and antigenicity. Exp. Mol. Pathol. 18: 202, 1973 .

McCullagh, K. and Ehrhart, L.: Increased arterial collagen synthesis in experimental canine atherosclerosis. Atherosclerosis, 19: 13, 1974 .

McCullagh, K. and Belian, G.: Collagen characterization and cell transformation in human atherosclerosis. Nature, 258: 73,1975 .

MCCullagh, K. and Sweet, M.: Characterization of the collagen synthesized by cultured rabbit and marmoset aortic smooth muscle celis. (in press), 1979.

Merchant, D.J., Kahn, R.A., and Murpiny, W.H.: "Handbook of Cell and Organ Culture." Second Edition, Burgess Publishing Company, Minneapolis, Minnesota, 1969.

Mikulicich, G. and Oester, T.: The inhibition of the epinephrinethyroxine induced arteriosclerosis by phentolamine. Angiology, 21: 421, 1970 .

Milier, E.J., Epstein, E.H. and Piez, K.A.: Identification of three genetically distinct collagens by cyanogen bromide cleavage of insoluble numan skin and cartilage collagen. Biochem. Biophys. Res. Comm., 42: 1024, 1971. 
Moczar, M. and Robert, L.: Extraction and fractionation of the media of the thoracic aorta: Isolation and characterization of structural glycoproteins. Atherosclerosis, 11: 7,1970 .

Moczar, M., Moczar, E. and Robert, L.: Composition of glycopeptides obtained by oroteolytic digestion of the media of procine aorta. Atherosclerosis, 12: 13, 1970.

Moss, N.S. and Benditt, E.P.: Human atherosclerotic plaque cells and leiomyoma cells. American J. of Pathology, 78: 175,1975 .

Mullinger, R.N. and Marley, G.: Elevated glycoprotein content in atherosclerotic aorta. J. Atheroscler. Res., 9 : 108,1969 .

Nakamura, T., Tokita, K., Tateno, S., Katoku, T. and Ohba, T.: Concentration of component sugars of glycoproteins from normal and atherosclerotic aortas. J. Atheroscler. Res., 8: $891,1968$.

Neville, D.: Molecular weight determination of proteindodecyl sulfate complexes by gel electrophoresis in a distoninuous buffer system. J. Biol. Chem., 246: 6328, 1971.

Nimni, M.: Collagen: Its sturcture and function in normal and pathological connective tissue. Seminars in Arthritis and Rhumatism, $\underline{4}$ (2): 95, 1974 .

Okasaki, K. and Holtzer, H.: Myogenesis-Fusion, myosin synthesis and the mitotic cycle. Proc. Nat. Acad. Sci., 56: 1484,1966 .

Doshima, A., Fuller, G., Cardinale, G., Spector, S. and Udenfriend, S.: Increased collagen synthesis in blood vessels of hypertensive rats and its reversal by antihypertensive agents. Proc. Nat. Acad. Sci., 7느: 3019, 1974.

Partridge, S.M., Elsden, D. and Thomas, J.: Constitution of cross-linkages in elastin. Nature, 197: 1297, 1963.

Partridge, S.M.: Chemistry and Molecular Biology of the Intercellular Matrix. E.A. Balazs, ed., Vol. 1, pp. 593616. Academic Press, V.Y., 1970.

Partridge, S.u.: In "The Comparative Molecular Biology of the Extracellular Matrices." H.C. Slavkin, ed., P. 388. Academic Press, N.Y., 1972.

Penttinen, R.P., Iichtenstien, J.R. Martin, G. and McKusick, $V .:$ Abnormal collagen metabolism in cultured cells in osteogenesis imperfecta. Proc. Nat. Acad. Sci., 72: 586, 1975 . 
Peterkofsky, B. and Diegelmann, R.: Use of a mixture of proteinase-free collagenases for the specific assay of radioactive collagen in the presence of other proteins. Biochemistry, 10: 988, 1971.

Pierard, G. and Lapiare, C.: Shizt in collagen types with simultaneous changes in mechanical properties during fetal development. Arch. Int. Bioch. Physiol., 84 (suppl. Eascicule 3), abst. 91, 1976.

Pope, F., Martin, G., Lichenstein, J., Penttinen, R., Gerson, B., Rowe, D. and Mckusick, V.: Patients with Ehlers-Danlos Syndrome Tyce IV lack type III collagen. Proc. iJat. Acad. Sci., 72: i314, 1975 .

Rhodes, R. and Miller, E.: Physiochemical characterization and molecular organization of the collagen $A$ and $B$ chains. Biochemistry, 17: 3443, 1978 .

Robbins, S.L.: IN "Pathological Basis of Disease," pp. 92-103, Sprıngfield, Ill., Chales C. Thomas, 1974.

Robert, L. and Poullain, N.L.: In "Enzymologie et Immunologie dans loatheroscleroses," Colloque Bordeaus, H. Bricaud, ed., pp. 123-129, Bailleres, Paris, 1964.

Robert, I.: In "Arteriosclerosis." Proceeding from the second international symposium I969, R.J. Jones ed., pp. 59-68, Springer-Verlag, Berlin, 1970.

Ross, R.: The smooth muscle cell II. Growth of smooth muscle in culture and formation of elastic fibers. J. Celi Biol., 50: 172,1971 .

Ross, R. and Bornstein, P.: The elastic fiber I. Separation and partial characterization of its macromolecular components. J. Cell Biol., 40: 366, 1969.

Ross, R. and Glomset, J.A.: Atherosclerosis and the arterial smooth muscle cell. science, 180: 1332, 1973.

Rounds, D.E., Booher, J. and Guerrero, R.R.: Consideration of atheroscotic plaques as benign neoplasms. Atherosclerosis, 25: 183, 1976.

Ross, R. and Vogel, A.: The platelet-derived growth factorRevier. Cell, 14:203, 2978.

Scott, D., Harwood, R., Grant, :1. and Jackson, D.: Characterization of the major collagen species present in porcine aortae and the synthesis of their precursors by smooth muscle cells in culture. Connective Tissue Res., 루 $7,1977$. 
Schoenebeck, L., Weber, U. and Voigt, K.: Glycoprotein content of arteriosclerotic aorta. J. Atheroscler. Res., 2 : 332,1962 .

Scornik, O.A.: Decreased in vivo disappearance of labelled liver protein after partial hepatectomy. Biochem. Biophys. Res. Comm., 47: 1063, 1972 .

Serafini-Francassini, A., Wells, P. and Smith, J.: In "Chemistry and Molecular Biology of the Intercellular Matrix," E.A. Balazs, ed., p. 1201, Vol 2, Academic Press, N.Y., 1970.

Seyer, J., Hutcheson, E. and Kang, A.: Collagen polymorphism in idiopathic chronic pulmonary fitrosis. J. Clin. Invest., 57, 1498, 1976 .

Siegel, R., Pinnell, S. and Martin, G.R.: Crosslinking in collagen and elastin. Properties of lysyl oxidase. Biochemistry 9: 4486,1970 .

Slavkin, H.C.: In "The Comparative Molecular Biology of Extracellular Matrices." H.C. Slavkin, ed., Academic Press, New York, 1972 .

Smith, E.: The influence of age and atherosclerosis on the chemistry of aortic intima, Part 2 (Collagen and mucopolysaccharides). J. Atheroscler. Res., 5: 241, 1965.

Smith, H.S., Scher, C. and Todaro, G.: Induction of celI division in medium lacking serum growth factor by SV-40. Virology $44: 359,1971$.

Somlyo, A., and Somloy, A.V.: Vascular Smocth Muscle. Pharmaclogical Reviews 20: 197, 1968.

Srinivasan, S.R., RadhakrishnamurtIy, B., Pargaonkar, P.S. and Berenson, G.S.: Glycoprotein from connective tissue of twins. Nature 229: 58, 1971 .

St. Clair, R.W. and Leight, M.A.: Differential effects of isolated lipoproteins from normal and hypercholesterolemic rhesus monkeys on cholesterol esterification and accumulation in arterial smooth muscle cells in culture. Biochim. Biophys. Acta. 530: 279, 1978.

Tami, M., Seppala, A., Jehtonen, A. and Mottonen, M.: Connective tissue components in normal and atierosclerotia human coronary arteries: Atheroscierosis 29: 191, 1978.

Thunell, S.: Procedures for the micro scale investigation of vessel wall glycosaminoglycans. Acta Uin. iund., Section II, No. 9, 1957 . 
Trelstad, R.L.: Human aorta collagen: Evidence for three distinct species. Biochim. Biophys. Res. Comm., 37, 717, 1974 .

Wexler, B.C. and Thomas, I.L.: Growth of aortic explants and arteriosclerosis. Nature 214: 243, 1967.

World Health Organization: World Health Organization, Tech. Rep. Ser., 143: 4, 1958. 


\section{VITA}

Douglas O. Fisher was born on May 15, 1948 in Pittsburgh Pennsylvania. Dr. Fisher entered the University of Rhode Island in 1966 and received his Bachelor of Science Degree in Pharmacy in 1971. In 1973 he completed a residency program in Hospital Pharmacy at Roger williams General Hospital, Providence, Rhode Island. Dr. Fisher then continued his education at the University of Rhode Island in the Department of Pharmacology and Toxicology, completing the requirements for Master of Science degree in March 1976 and Doctor of Philosophy in March 1979.

Throughout his graduate training Dr. Fisher worked as a technician for the University of Rhode Island Crime Laboratory. He is a member of Sigma Xi research society, American Society of Hospital Pharmacists and Rhode Island Society of Hospital Pharmacists.

Dr. Fisher has accepted a position as a toxicologist in the Department of Drug Safety Evaluation at Pfizer Inc., Groton; Connecticut.

Dr. Fisher is married to the former Kathleen N. Osborne of Warwick, Rhode Island. 